\title{
iPSCs-based generation of vascular cells: reprogramming approaches and applications
}

\author{
Diana Klein ${ }^{1}$
}

Received: 6 July 2017 / Revised: 8 December 2017 / Accepted: 11 December 2017 / Published online: 14 December 2017

(c) The Author(s) 2017. This article is an open access publication

\begin{abstract}
Recent advances in the field of induced pluripotent stem cells (iPSCs) research have opened a new avenue for stem cell-based generation of vascular cells. Based on their growth and differentiation potential, human iPSCs constitute a well-characterized, generally unlimited cell source for the mass generation of lineage- and patient-specific vascular cells without any ethical concerns. Human iPSCs-derived vascular cells are perfectly suited for vascular disease modeling studies because patientderived iPSCs possess the disease-causing mutation, which might be decisive for full expression of the disease phenotype. The application of vascular cells for autologous cell replacement therapy or vascular engineering derived from immunecompatible iPSCs possesses huge clinical potential, but the large-scale production of vascular-specific lineages for regenerative cell therapies depends on well-defined, highly reproducible culture and differentiation conditions. This review will focus on the different strategies to derive vascular cells from human iPSCs and their applications in regenerative therapy, disease modeling and drug discovery approaches.
\end{abstract}

Keywords iPSC $\cdot$ Reprogramming $\cdot$ Differentiation $\cdot$ Vascular cell $\cdot$ Endothelial cell $\cdot$ Smooth muscle cell

\section{Introduction}

Induced pluripotent stem cells (iPSCs) are reprogrammed cells that have features similar to embryonic stem cells, such as self-regeneration without restriction and differentiation into different tissue or cell types, including vascular cells [1]. Connected with these cells is the hope that 1 day they could be used as an inexhaustible source to restore damaged or diseased body tissue $[2,3]$.

Artificial reprogramming of somatic cells produces cells that maintain their great potential for medical use but research is associated with less ethical problems than embryonic stem cells resulting from the internal cell mass of blastocysts (embryoblasts) $[4,5]$. In principle, iPSCs have the potential to differentiate into various adult human cell types and tissues. Although it is a long way from a few cells in a Petri dish to a complex, functional tissue that could replace an injured or diseased organ, the exciting and medically

Diana Klein

Diana.Klein@uk-essen.de

1 Institute for Cell Biology (Cancer Research), University Hospital Essen, University of Duisburg-Essen, Virchowstr. 173, 45122 Essen, Germany important duty of iPSCs research is to understand the basic controlling mechanisms of nature and to learn how stem cells approach differentiated cells and transform into certain tissues. Furthermore, iPSCs turned out to be a realistic method for obtaining patient-specific stem cells and using them for the investigation of diseases and their therapy, e.g. development of drugs or toxicological testing of chemical substances, as well as their use as target cells for individualized and targeted gene therapy [6].

The vascular system is essential for embryonic development and adult life and it is the first organ system to develop during vertebrate embryogenesis $[7,8]$. Herein, endothelial cells arise from mesodermal precursors around embryonic day E8.5, and the first primitive vascular network remodels and matures between E9.5 and E12.5 [7, 9-11]. These remodeling and maturation processes involve the recruitment of vascular mural cells: pericytes ensheath capillary endothelial cells, whereas smooth muscle cells (SMC) surround endothelial cells in arteries, arterioles, venules and veins, which is critical for proper vascular development, stabilization, and maintenance. An ordered remodeling is an absolute prerequisite to preserve the sensitive relationship between resilience and stability of the vessels [12]. In the healthy state adult blood vessels are usually quiescent, which 
means a non-proliferating, anti-thrombotic, anti-inflammatory and non-angiogenic default status of resting endothelial cells. SMC in the arterial wall are mostly quiescent but can display a contractile phenotype in adults. Under pathophysiological conditions, vascular remodeling after endothelial dysfunction or damage is directly or indirectly associated with multiple common human diseases: atherosclerosis, thrombosis, hypertension, ischemic diseases, congenital vascular lesions (aneurysms, fibromuscular hyperplasia, and stenosis in collaterals), shear stress, irradiation, and even tumor growth $[13,14]$.

The task of blood vessels involves transporting of all the nutrients as well as of their metabolites, e.g. of toxic waste. The goal is an optimal supply of all cells of the body and the blood circulation with vital substances [15-17]. Anatomically, the wall of all larger blood vessels-whether arteries or veins-viewed from the inside outwards is basically constructed from three different layers. The innermost layer (also called tunica intima), which is composed of a single continuous layer of endothelial cells, is in direct contact with the blood flow and mediates the exchange of nutrients and cells with the circulation. The middle layer (tunica media), which consists of SMC, is responsible for the maintenance of the vessel tone and elasticity. The outer layer (adventitia), which consists of connective tissue, harbors fibroblasts and the small network of vessels that provides oxygen and nutrients to the cells in the vessel wall (vasa vasorum) [18]. Herein, the endothelial cells are key components for maintaining the function of the vessels by regulating endothelial permeability, modulating the vascular tone and regulating blood coagulation. The vessel diameter can be changed by the contraction of their muscle cell layer(s), whereby blood vessels control the distribution of blood volume and thus regulate the oxygen supply. In addition, it keeps individual body regions in the core temperature.

Vascular damage and dysfunction are implicated in the development of vascular diseases and cardiovascular pathological changes. Therefore, the therapeutically use of autologous cells for tissue regeneration is a ray of hope, which includes both local transplantation of the vascular cells to injured organs and the engineering of organs. Cell replacement therapy with vascular cells and vascular bypass grafts with autologous blood vessels or synthetic vascular grafts are the main treatments for certain cardiovascular diseases, such as coronary heart disease, aortic aneurysm, dissection, and peripheral vascular disease [19-23].

The main limitations for the use of vascular cells for the treatment of cardiovascular diseases were the sources and amount of the cells. In general, their proliferative potential decreases with increasing donor age and intensive ex vivo expansion can limit their properties such as long term plasticity and result in a functional decline. In addition, adult cells may contain more DNA abnormalities (caused by sunlight, toxins and errors in making DNA copies) during the course of a lifetime [24-26]. Thus, finding a reliable source of cells remains an important problem. To circumvent many of these issues, an alternative method to gain vascular cells is the in vitro differentiation of iPSCs, which are one of the most appropriate basic cell sources (Fig. 1) [27-30]. Human iPSC-derived vascular cells display similar features with mature vascular cells at the genetic and functional levels.

The unlimited proliferation potential of iPSCs and their capability to differentiation into virtually every cell type in the human body is of great significance to explore alternative cell sources capable of generating functional endothelial cells and SMC. Furthermore, the generation of structures to repair damaged endothelium for vascular regeneration as well as blood vessels en bloc were desired because endothelial cell regeneration is a slow and insufficient process [31, 32]. Tissue-engineered vascular grafts for examples are promising novel alternatives to replace diseased vessels. Herein generating enough functional and clinically usable vascular cells for conducting these vascular grafts remains a major challenge [21].

Beside the abundant origins of iPSCs the potential to generate patient individualized vascular cells that bypass the immunogenicity and ethical issues are central advantages of using iPSCs as vascular cell source. However, a possible therapeutic use of pluripotent stem cells still holds medical risks, namely the potential to generate teratomas. Therefore, only donor cells that have reached a particular differentiation stage could be used, which means that the iPSCs must first be brought to an ordered differentiation path. Thus, a major obstacle for using human iPSCs for therapy or to model disease remains the lack of reliable, efficient and scalable protocols to differentiate functionally mature adult cell types.

Based on progress in the research field, the present review aims to summarize the strategies and mechanisms of generating vascular cells through differentiating from human iPSCs, and to examine what this means for the potential application of cell therapy in the clinics.

\section{Reprogramming approaches}

In mammalian development, vascular progenitors mainly emerge from the lateral and posterior mesoderm [33]. Thus, vascular cells can be derived from differentiating iPSCs via three primary strategies: (1) iPSC differentiation towards the mesoderm followed by cell-type specific growth factor treatment, (2) culture on polymer coatings (extracellular matrix) in the presence of soluble, signaling molecules, and (3) genetic manipulation of iPSCs by ectopic expression of lineage or cell-type specific transcription factors (Fig. 2). 


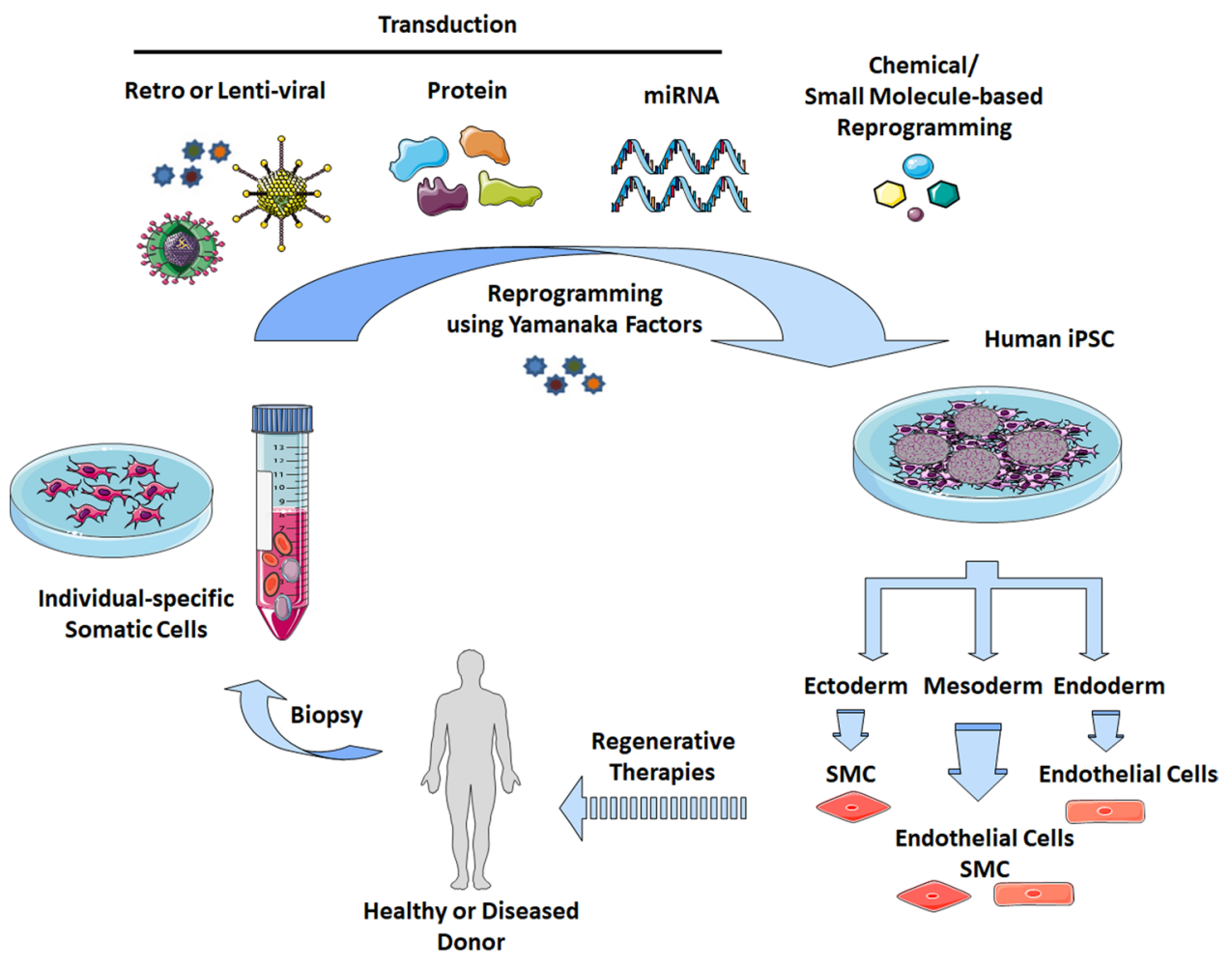

Fig. 1 Induced reprogramming of somatic cells. Somatic cells (e.g. fibroblasts, peripheral blood cells) can be isolated from individual healthy or diseased donors (biopsy) and directly reprogrammed into human iPSCs by the introduction of the common transcription factors $O C T 4, S O X 2, K L F 4$ and $c-M Y C$ (Yamanaka factors) via retro-/ lentiviral transduction, protein and microRNA transduction, or by chemical/small molecule-based reprogramming strategies. iPSCs were characterized by indefinite self-renewal and pluripotent differentiation capacities, and thus represent an attractive source to generate

Induction of mesodermal differentiation can be achieved using conditions that promote self-aggregation of the iPSCs into three dimensional embryoid bodies (EB) or by the addition of mesoderm-inductive factors in chemically defined monolayer systems. The evolutionarily most ancient family members Nodal, Activin and BMP are members of the transforming growth factor $\beta$ (TGF $\beta$ ) superfamily of morphogens, which includes TGF $\beta$ s, inhibins, bone morphogenetic proteins (BMPs), growth and differentiation factors (GDF), and others [34-36]. Combined gradients of Nodal and BMP signaling within the primitive streak initiate germ layer formation, control endoderm and mesoderm germ layer specification and also their subsequent patterning whilst blocking neuroectoderm formation [37, 38]. Activin/Nodal signaling achieves mesendoderm specification by interacting with other key signaling pathways, especially BMP and WNT, whereby WNT signaling also plays an essential function in mesoderm formation by blocking the PI3K/ERK pathway, and thereby inhibiting GSK3 $\beta$, which is known to induce mesoderm differentiation [39, 40]. Another important factor unlimited cell numbers for targeted differentiation, in principle, into the entire range of cell types found in the body via multiple lineages (ectoderm, endoderm and mesoderm). The generation of patient- and disease-specific iPSCs is a valuable tool for (1) regenerative therapies, e.g. restoration of function through transplantation of manufactured cells and tissues, (2) exploring disease etiology and associated pathophysiologic mechanisms, and (3) developing novel drugs and toxicology screening. iPSC, induced pluripotent stem cell; SMC, smooth muscle cell; miRNA, microRNA

is the fibroblast growth factor (FGF). FGF contributes to this process not only by promoting mesoderm formation, but also by inhibiting endodermal development [41]. Therefore, Activin and Nodal are essential for mesodermal induction, while FGF and WNT are in charge of its maintenance, and BMP is responsible for its patterning. Activin A/Nodal, BMP4, FGF2, and WNT ligands (e.g. WNT3A) or GSK3 inhibitors (canonical WNT activators, e.g. CHIR-99021) were the currently the most used mesoderm-inductive factors. Induced mesodermal progenitor cells were demonstrated to bear then a bi-potent differentiation potential with the ability to generate endothelial and SMC lineages [42].

No matter which way of mesodermal induction is chosen, the different lineages of vascular cells emerge then from the proliferating and differentiating iPSC in the presence of growth factors, extracellular matrix molecules, growth factor inhibitors, small molecules, and neutralizing antibodies that can be used to promote enrichment of the endothelial cells or SMC or the lineage of choice. To identify the cell lineage of choice and to enrich the cells using some form of 


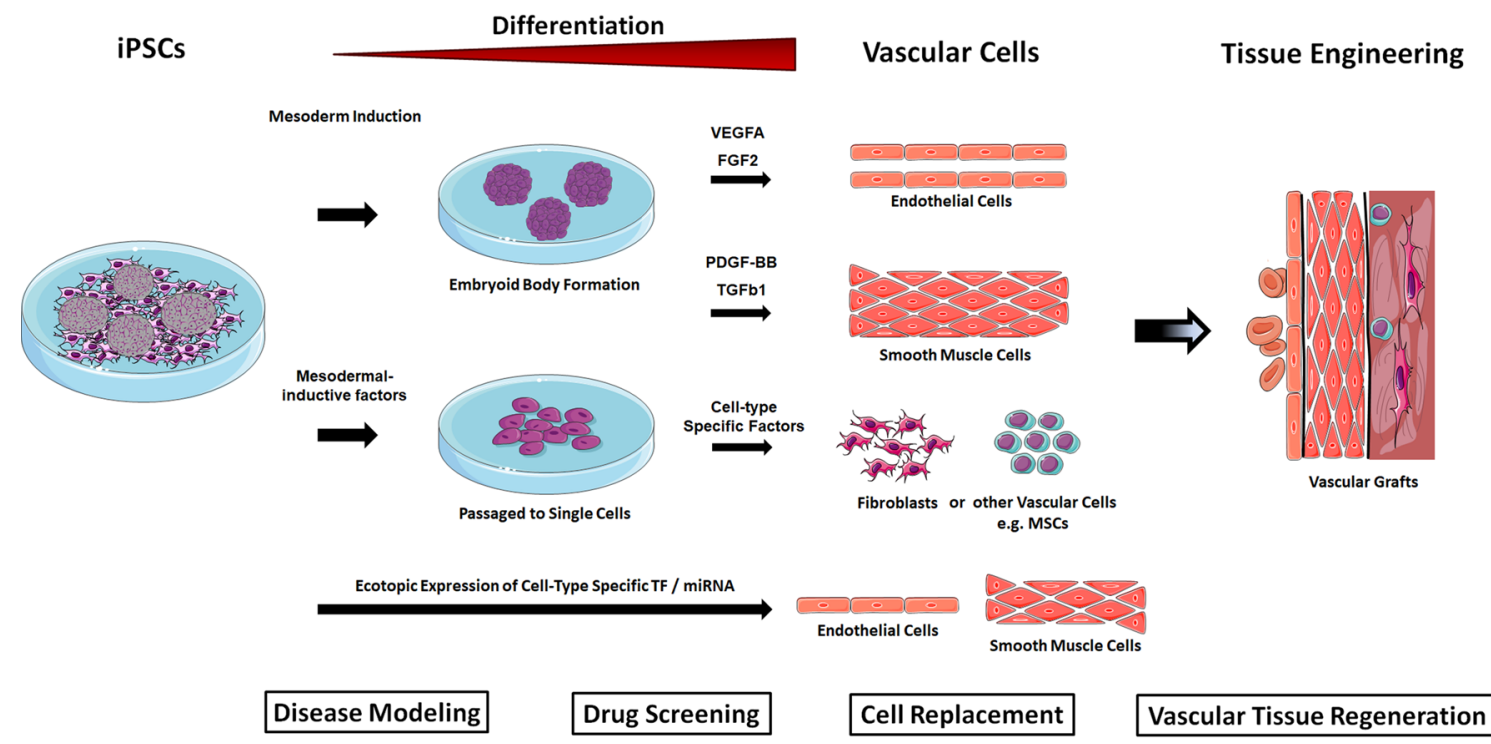

In Vitro / In Vivo (Animal Models)

Clinical Applications

Fig. 2 iPSCs-based generation of vascular cells. iPSCs are capable of self-renewal and differentiation into any cell type in the human body, and thus are attractive resources to generate unlimited numbers of vascular cells. Differentiation of iPSC is initiated by induction of mesodermal differentiation either in conditions that promote self-aggregation of the iPSCs into three-dimensional embryoid bodies (EB) with or without additional mesodermal-inductive factor treatment; or by the addition of mesodermal-inductive factors (BMP4, Activin A/Nodal, FGF2, and GSK3 inhibitors or WNT ligands) in chemically defined monolayer systems. Successive treatment with cell-type-specific growth factors for the desired cell types allows then the isolation and expansion of the selected vascular cells under chemically defined cell-culture conditions. Sorting for cell-type-specific cell surface markers using flow cytometry or immunomagnetic sepa-

cell sorting and isolation (flow cytometry sorting or immunomagnetic separation), monoclonal antibodies to identify specific cell surface molecules or genetic tagging of the iPSC with lineage-specific fluorescent reporter systems are required. Subsequent additions of numerous growth factors (as described below) further promote vascular cell proliferation, differentiation and eventual maturation during the in vitro culture.

\section{Reprogramming to endothelial cells}

Endothelial cells originate mainly from mesodermal progenitors [43]. Shortly after gastrulation endothelial cells become organized into the primary vascular plexus which marks the onset of vascular development. Subsequent remodeling of the endothelial vasculature takes place, recruitment and integration of SMC and pericytes finally result in a complex vascular system. Thus, endothelial cells as the inner lining of blood vessels are diversified ration might further be used to increase purity of generated vascular cells. Human iPSC-derived vascular cells, in particular endothelial cells and smooth muscle cells turned out to be a realistic method for obtaining patient-specific cells and using them for the investigation of diseases and their therapy. These cells represent a potentially valuable tool for the development of robust and reproducible vascular tissues (stem cell-based vascular engineering) for disease modeling and drug screening applications. Hypothetically, vascular cells could also be obtained by a direct programming approach, namely by ectopic (over-)expression of vascular cell-specific transcription factors (TF) in human iPSCs or by the introduction of cell-type specific microRNA (miR) molecules that functions in RNA silencing and post-transcriptional regulation of vascular gene expression

from simple capillaries formed by single endothelial cells into large multi-layered conduit vessels in the arterial, venous, and lymphatic systems. Beside vessel heterogeneity, even tissue heterogeneity of endothelial cells within specific tissues and organs prevail as revealed by specific angiocrine factors in modulating tissue functions [44-46]. Therefore, targeted profiles for tissue specific endothelial cell phenotypes have become of interest for scientists generating EC from iPSC [44, 47, 48].

Various methods have already been disclosed to generate endothelial cells from human iPSCs [44, 47, 49-52]. Two groups reported some of the first approaches to differentiate iPSCs toward endothelial cells in 2009. Taura et al. cocultured human iPSCs with OP9 feeder cells for 10 days and observed the emergence of a VEGFR2-positive population with an endothelial cell differentiation capacity [53]. Using a similar approach, Choi et al. co-cultured different human iPSC lines with the same feeder cells for 8 days and then selected CD34- and CD31-double positive cell populations which could give rise to functional endothelial cells after 
additional 7 days under endothelial-promoting culture conditions [54].

Later on, more commonly endothelial lineage-committed cells could also be derived from EB formed by iPSCs. The first reported EB differentiation-based methods used high VEGF concentrations and resulted in less than $10 \%$ of CD31/PECAM1-positive cells after 2 weeks of culture [55-58]. Although recent advances have achieved higher efficiencies (up to 50\% CD31-positive cells), the efficiencies are difficult to scale up because their methodology is based on EB/aggregate formation; and these results could not be replicated on several pluripotent stem cell lines [47, $59,60]$. Moreover, EB formation results in differentiation of iPSCs into various cell types, including endothelial cells, albeit inefficiently. EB differentiation is often time-consuming, with the peak expression of endothelial genes occurring after $10-15$ days.

Nowadays, monolayer differentiation methods of feederfree culture systems without the need of previous EB generation but with the combination of different culture substrates and chemical-defined conditions have been successfully applied to induce endothelial cells from iPSCs and were most commonly used. These improved methods resulted in an increase in differentiation fidelities, efficiencies and kinetics.

An alternative, technically more straight forward monolayer differentiation method was described in 2012 by Lippmann et al., who investigated a custom 2D human iPSC differentiation strategy that promotes neural and blood-brain-barrier endothelial cell co-differentiation [61]. Herein, human iPSCs (IMR90-4 cell line induced from fetal fibroblasts; DF6-9-9T and DF19-9-11T cell lines induced from foreskin fibroblasts) were maintained on irradiated mouse embryonic fibroblasts in standard unconditioned medium (DMEM/Ham's F12 containing knockout serum replacer (KOSR), nonessential amino acids, L-glutamine, beta-mercaptoethanol, and human FGF2) [62, 63]. Shortly, bevor induction of endothelial differentiation iPSCs was passaged onto Matrigel in mTeSR1 medium. Differentiation was induced by switching to unconditioned medium lacking FGF2 (UM media). After 5-7 days when major morphological changes were observed the medium was replaced by an endothelial cell medium (human endothelial serumfree medium supplemented with FGF2 and platelet-poor plasma derived bovine serum). After additional 1-2 days differentiated iPSCs were plated onto polystyrene culture plates coated with a mixture of collagen-IV and fibronectin. This procedure yielded up to $95 \%$ combined neural and endothelial cell populations of the total differentiating culture at day 6 of UM treatment [61]. The 2 days-culture in endothelial cell medium further expanded the brain microvascular endothelial cells percentage (of GLUT1 and PECAM1/CD31-positive cells) to $66 \%$ in differentiating
iPSC cultures. A slightly modification of the protocol mainly concerning the incubation times and not the factors used for differentiation of brain microvascular endothelial cells from iPSCs (BC1 cell line induced from blood cells) was recently provided by Katt et al. [64]. The addition of retinoic acid in differentiated endothelial cell cultures further upregulated expression levels of the mature endothelial cell marker VE-Cadherin and resulted in a significant increase in trans-endothelial electrical resistance to physiological values $[64,65]$.

In 2014, Orlova et al. described an elegant and very detailed protocol for the generation, expansion and functional analysis of endothelial cells (as well as pericytes) from human iPSCs under defined conditions [52]. Herein, substantial numbers of endothelial cells could be derived in only $2-3$ weeks, including differentiation (10 days), immunomagnetic isolation (1 day), and expansion of CD31-positive endothelial cells (4-10 days) [52]. The differentiation protocol was tested and simplified for the use on multiple human iPSC lines, derived from either skin fibroblasts or blood outgrowth endothelial cells by transduction with either retroviruses or lentiviruses [52, 66]. Initiation of differentiation was performed in iPSC monolayers classically cultured on Matrigel-coated plates in mTeSR 1 medium by replacing mTeSR 1 medium with mesoderm induction medium $[\mathrm{B}(\mathrm{P})$ EL medium [57] containing Activin A, BMP4, VEGF and CHIR-99021 (small-molecule inhibitor of glycogen synthase kinase-3 $\beta$ )] for 2 days. On day 3 , when first mesenchymal cells could be observed, mesoderm-inductive factors were replaced with vascular specification medium supplemented with VEGF and the TGF $\beta$ pathway small-molecule inhibitor SB431542 to support the expansion of endothelial cells while inhibiting the anti-proliferative activities of cellderived TGF $\beta$-like factors that are also present in the culture [52]. The earliest endothelial cells could be observed on day 6-7 of differentiation. At day 10 of differentiation, the total cell yield of mature VE-Cadherin and CD31-positive endothelial cells was about $10 \%$. CD31-positive cells were further purified via immunomagnetic separation and expanded in endothelial cell serum-free medium (EC-SFM) to which platelet-poor plasma serum, VEGF and FGF2 was added. Functionality of endothelial cells differentiated from human iPSCs was demonstrated by primary vascular plexus formation upon co-culture with iPSC-derived pericytes and by incorporation in the vasculature of zebrafish xenografts in vivo $[52,66]$.

As vascular progenitors and in particular endothelial lineage cells in mammalian development emerge from the lateral and posterior mesoderm, and canonical WNT signaling was shown to play a decisive role in mesoderm commitment during embryogenesis, Patsch et al. investigated selective GSK3 $\beta$ inhibitors that promoted efficient commitment of human iPSCs towards mesoderm prior differentiation into 
endothelial cells [50]. WNT signaling directs differentiation of iPSCs into mesoderm and GSK3 $\beta$ inhibition activates this pathway. Thus, GSK3 $\beta$ inhibition and BMP4 treatment rapidly committed iPSCs to a mesodermal fate and subsequent exposure to VEGF resulted in the differentiation of mature endothelial cells with efficiencies over $80 \%$ within 6 days. Herein, CP21 and CHIR were the most selective GSK3 $\beta$ inhibitors. For differentiation, human iPSCs plated as single cells were treated with CP21 or CHIR and/or BMP4 for 2 days to foster mesodermal induction and then treated with VEGF to induce the endothelial cells. At day 5, endothelial cell differentiation was confirmed by analyzing the expression of VE-Cadherin via FACS and revealed that only BMP4 and CP21 or CHIR combined were capable of inducing high levels of endothelial cell marker expressing cells (up to 35\% VE-Cadherin-positive cells), whereas treatment with BMP4 alone led to fewer than 10\% VE-Cadherinpositive cells. A additional combined VEGF treatment with Forskolin (a potent cyclic AMP inducer known to activate kinase A resulting in an increase in vascular development) for 2 days, followed by VEGF treatment alone for additional 4 days promoted the differentiation of iPSCs into endothelial cells with efficiencies between up to $90 \%$ of cells. MACSmediated selection for VE-Cadherin expressing endothelial cells then obtained virtually pure cultures [50].

The efficient and robust differentiation of endothelial cells from human iPSCs via lineage control with VEGF in combination with cyclic AMP was further stressed by a recent study of Ikuno et al. which demonstrated that cyclic AMP synergistically enhanced the VEGF effects in serum-free 2D monolayer cultures [67]. The authors controlled the direction of differentiation from mesoderm to endothelial cells using stage-specific stimulation with VEGF and cyclic AMP combined with the elimination of non-responder cells at early endothelial stages. This stimulation-elimination method robustly achieved very high efficiency (up to 99\%) with no need of purification of endothelial cells after differentiation [67].

Very recently, Harding et al. developed a robust protocol to differentiate human iPSCs into endothelial cells with high purities in 8 days without cell sorting [68]. Here the protocol started also with the induction of mesoderm formation from iPSCs using the GSK3 inhibitor CHIR99021 for 2 days, which activated the WNT signaling pathway. A further treatment of iPSC-derived mesoderm with VEGF, BMP4, or FGF2 individually or in combinations for 2 days for the induction of vascular progenitors differentiation revealed that VEGF alone only moderately induced the expression of endothelial lineage markers such as VE-Cadherin and CD31. The combination of BMP4 and VEGF further increased the number of cells expressing CD31 and VE-Cadherin, whereas FGF2 alone failed to do so. However, the highest number of cells being positive for endothelial lineage markers was achieved with the combination of VEGF, BMP4, and FGF2, which was significantly higher than those with only VEGF and BMP4 combined [68]. The vascular progenitors were further grown in endothelial-specific growth medium (ECGM-MV2) supplemented with additional VEGF for 4-6 days yielding 95\% CD31-positive and 80\% VECadherin-positive endothelial cells. Functionality of those iPSC-derived endothelial cells was demonstrated by their ability to form patent blood vessels that were connected to the host vasculature in the ischemic limbs of immunedeficient mice.

Another straight forward-but up to now quite theoretical-strategy would be the ectopic overexpression of endothelial related transcription factors (TF) in human iPSCs to generate endothelial cells. Especially FOX and ETS transcription factors are potent regulators for vascular development and angiogenesis, that regulate almost all typical endothelial markers [69-71]. Although a couple of endothelial-specific TF were identified, introduction of these factors to generate endothelial cells were restricted to somatic cell types, in particular fibroblasts of different origins $[69,72,73]$. Major concerns about using the target cell-specific TF for direct cell lineage reprogramming are: (1) to establish stably proliferative endothelial populations, a more precise temporal control on gene overexpression is needed and (2) the original gene regulatory network of the starting cell type may be insufficiently inactivated in the differentiated population [74]. Thus, it remains elusive whether the forced expression of selected endothelial cell-specific TF in human iPSCs would result in endothelial cell differentiation as already demonstrated for murine mouse embryonic stem cells $[75,76]$. From murine iPSCs it is further known that specific micro-RNA (miR) regulate endothelial lineage emergence from differentiated iPSCs [44]. For example, miR-21 was one of the most overrepresented miR expressed, when murine embryonic stem cells were differentiated into endothelial cells and miR-199 was increased in a step-wise fashion when murine embryonic stem cells differentiate into endothelial cells $[49,77]$. However, corresponding investigations using human iPSCs remain again elusive.

\section{Endothelial cell heterogeneity}

In general, as shown by the numerous studies listed above, the isolation of endothelial cells primarily relies on general endothelial surface markers such as KDR/VEGFR2, CD31/PECAM1, or CD144/VE-Cadherin, which in turn means that generated endothelial cells might represent different endothelial subtypes: arterial, venous, and lymphatic endothelial cells. Endothelial cells exhibit a high degree of heterogeneity across vascular classes and tissue types, e.g. micro-/macro-vascular endothelial cells and sinusoidal 
endothelial cells $[48,78,79]$. Therefore, Rufaihah et al., investigated if endothelial subtypes can be enriched upon iPSC-endothelial cell differentiation [78]. The authors used HUF4 and HUF5 iPSCs generated from adult dermal fibroblasts to demonstrate that the specification of arterial or venous subtype upon endothelial cell differentiation from iPSCs is influenced by the concentration in the media of VEGF. Herein, high VEGF-A concentrations $(\sim 50 \mathrm{ng} / \mathrm{ml})$ and 8Br-cAMP (8-bromoadenosine-3':5'-cyclic monophosphate sodium salt) induced arterial CD31-positive endothelial cells in association with increased expression of the Notch pathway, whereas lower VEGF concentrations $(\sim 10 \mathrm{ng} / \mathrm{ml})$ induced venous CD31-positive endothelial cells. In contrast, high VEGF-A and VEGF-C concentration with the supplementation of angiopoietin 1 in the medium promoted the specification to lymphatic CD31-positive endothelial cells [78]. Interestingly, iPSC-derived endothelial cells of the arterial subtype showed the best potential to form extensive and mature capillary networks in vivo, clearly indicating that refining the differentiation methods can enrich for subtype-specific endothelial cells upon iPSC differentiation with functional benefits of enhancing neovascularization. Although, focusing on human embryonic stem cells only, Sriram et al. also reported the efficient differentiation of human embryonic stem cells to arterial and venous endothelial cells under feeder- and serum-free conditions using different VEGF concentrations, which offers a human platform to study arterial-venous specification for the various applications in the future [79].

Conclusively, robust protocols exist to differentiate human iPSCs successfully to endothelial cells that have great potential for mechanistic studies of endothelial cell differentiation as well as for individualized vascular therapy.

\section{Reprogramming to SMC}

Vascular SMC are crucial for vascular function providing contractile function and structural support to vascular blood vessels. SMC with more than one developmental origin still retain considerable plasticity and can modify their phenotype in response to vessel injury [80-82]. Most vascular SMC are largely derived from various mesodermal lineages such as splanchnic mesoderm, lateral plate mesoderm, and somatic or paraxial mesoderm and a subset of SMC originate from the neural crest, the secondary heart field and the pro-epicardial organ [81, 83-85]. Thus, many human iPSC-SMC differentiation protocols direct the cells toward an intermediate, origin-specific lineage before inducing the terminal SMC phenotype [86, 87].

Today, various embryonic stem cell-based differentiation strategies exist to induce in vitro differentiation of human iPSCs to SMC. In line with the protocols of differentiating human iPSCs to endothelial cells two major methods exist: (1) EB-induced differentiation with or without additional growth factor treatment to foster mesodermal induction, and (2) monolayer culture of iPSCs on extracellular matrix (ECM) coatings and by the use of defined chemical conditions followed by culture manipulations [31]. SMC differentiated from iPSCs might be further sorted using flow cytometry or immunomagnetic separation or enriched using selection medium to get pure SMC. With respect to the multiple origins of SMC during development, differentiating via the EB method might have an advantage of mimicking early embryonic development.

One of the first described EB-methods for differentiating SMC from human iPSCs was reported in 2010 when Lee et al. generated iPSCs from somatic human aortic vascular smooth muscle cells and differentiated these iPSCs then back into SMC [88]. Here, generated iPSC were cultured on mitomycin C-treated mouse embryonic fibroblasts as feeder cells in standard human embryonic stem cell medium. For SMC differentiation EBs were transferred to gelatin-coated plates and maintained in SMC-specific medium (SMCM) for 10 days. Colonies with SMC-like cell morphology were then manually picked, examined for the expression of SMCspecific marker genes, and further expanded [88].

In a modified EB-initiated differentiation method based on a protocol established for human embryonic stem cells, $\mathrm{Ge}$ et al. differentiated SMC from human iPSC clones which were established from foreskin fibroblasts and vascular SMC of patients with supravalvular aortic stenosis [89, 90]. Herein 6 days EB were plated on gelatin-coated culture dishes and cultured with fresh differentiation medium (DMEM supplemented with FBS, nonessential amino acids, $\beta$-mercaptoethanol and L-glutamine). On day 6 the small clusters obtained were dissociated and transferred to Matrigel-coated plates in SmGM-2 media. After 1 week of culture, cells were again transferred to gelatin-coated culture dishes and cultured with the low FBS (5\%) differentiation medium for at least 5 days to complete the differentiation. This quite simple method yielded SMC of mixed origin (mesoderm, ectoderm an/or endoderm-derived) in a purity of more than $95 \%$ as analyzed by calponin expressions [89].

A further more mesodermal-directed approach was reported by Lin et al. where L1 iPS and L2 iPS6 cells (human iPSC lines) reprogrammed from dermal fibroblasts cultured on mouse embryonic fibroblasts were used [91]. SMC were differentiated from 6 days EB which were pre-induced with VEGF and the WNT signaling inhibitor Dickkopf homologue 1 (DKK1) for 2 days. Activated leukocyte cell adhesion molecule ALCAM/CD166-negative (to exclude cardiomyocytes) were isolated via flow cytometry and further cultured with SMC-specific SmGM2 medium yielding over $90 \%$ smooth muscle actin (SMA/ACTA2)-positive SMC. A similar approach using 6 days EB pre-induced 
with VEGF and FGF2 for 2 days was reported within the same study. A successive prolonged culture as a monolayer for additional 14 days with VEGF and FGF2 yielded about $70 \%$ SMC. Finally, over $95 \%$ pure SMC were obtained after a negatively isolation for CD31-reactivity via flow cytometry [91].

\section{SMC heterogeneity}

Somatic SMC display a wide range of morphological and functional characteristics that are best described as a spectrum bounded by predominantly synthetic and contractile phenotypes [92-94]. Accordingly, it was already shown that human iPSC-derived SMC could be guided to acquire either a synthetic or a contractile phenotype [94]. By monitoring the expression of SM-MHC and elastin, the authors demonstrated the possibility of generating synthetic or contractile phenotypes from different human iPSC lines with appropriate concentrations of SMC-inductive factors (namely PDGF$\mathrm{BB}$ and TGF $\beta 1$ ) known to control these developmental steps in the early embryo and in adulthood. The human iPSC cell lines MR31 (derived from IMR90 fetal lung fibroblasts) and $\mathrm{BC}$ were grown on inactivated mouse embryonic fibroblast feeder layers in KO-DMEM supplemented with KOSR, GlutaMAX, FGF2, NEAA and $\beta$-mercaptoethanol. Differentiation into SMC was induced by plating the cells on collagenIV-coated plastic in a differentiation medium composed of alpha-MEM, FBS, and $\beta$-mercaptoethanol for 6 days. Differentiating iPSCs were re-plated onto collagen-IV-coated plates in differentiation medium supplemented with PDGFBB and TGF $\beta 1$ for additional 6 days (a total of 12 days) [94]. The long-term differentiation of these iPSCs in high serum (10\% FBS) with PDGF-BB and TGF $\beta 1$ successfully induced the synthetic SMC phenotype with increased ECM protein expression and reduced expression of contractile proteins, whereas serum starvation (0.5\% FBS) and PDGF-BB deprivation caused maturation towards the contractile SMC phenotype.

Recently, Yang et al. reported two novel iPSC-SMC differentiation protocols that yield SMC with predominantly contractile or synthetic phenotypes using human iPSCs that had been reprogrammed from human cardiac and dermal fibroblasts [86]. Both protocols begin by initiation of differentiation of human iPSCs (cultured in mTeSR medium on Matrigel-coated plates) using the GSK inhibitor CHIR99021 and BMP4 for 2 days. Differentiation into synthetic or contractile SMC began on day 3. Synthetic SMC were produced by culturing the cells with VEGF-A and FGF2 in RPMI1640 medium and 2\% B27 (without insulin) from day 3 to 7 , then with VEGF-A and FGF2 in RPMI1640 and 2\% B27 (with insulin) from day 7 to 10 , and with PDGF-BB and TGF $\beta 1$ in RPMI1640 and 2\% B27 from day 10 to 14. Contractile
SMC were produced by culturing the cells with VEGF-A and FGF2 in RPMI1640 and 2\% B27 from day 3 to 7, and with PDGF-BB and TGF $\beta 1$ in RPMI1640 and 2\% B27 from day 7 to 14 . Flow cytometry analyses of SMA expression indicated that $\sim 45 \%$ of the cells obtained with each protocol assumed an SMC phenotype. Additional purification was performed by maintaining the differentiated cells in $4 \mathrm{mM}$ lactate RPMI1640 metabolic medium for 4-6 days [86]. Thus, each protocol could be completed in 2-3 weeks (including the 4-6 days metabolic selection period) and yielded SMC populations that are $\sim 95 \%$ pure and remain phenotypically stable for at least 20 generations. In contrast to the contractile SMC, synthetic iPSC-derived SMC expressed less calponin, more collagen-I, and more connexin 43, were quite resistant to carbachol treatment while having higher cell migration and proliferation rates [86].

Of note, SMC from distinct anatomic locations were derived from different embryonic origins. This diversity was not specified in SMC generated via the EB method although a mesodermal developmental origin seemed to be obvious. However, these pioneering studies further proved the use of human iPSCs as an autologous cell source for patient-specific cell therapy [31]. Beside their potential for regenerative therapy, iPSCs have become an important tool for modeling and investigating human diseases, as well as for screening drugs [6]. Therefore, more defined protocols for generating human SMC subtypes of the distinct embryonic origins were needed for studying the influence of SMC lineage on the spatial specificity of vascular disease because the regional distribution of vascular diseases may partially be related to the inherent heterogeneity in SMC lineages.

In 2014, Cheung et al. showed in an very defined protocol how human pluripotent (embryonic) stem cells can be differentiated into distinct populations of SMC subtypes under chemically defined conditions [95]. With respect to the limitation that the present review focusses on iPSCderived vascular cells the important protocol of Cheung et al. is included due to the fact that the protocol was also proven to work for human iPSCs. Jiao et al. used the Cheung protocol to successfully differentiate human iPSCs reprogrammed from human peripheral blood cells (PBMCs) to paraxial mesoderm- and subsequently to paraxial-derived SMC [96-98]. Furthermore, the successful generation of human iPSC neural crest-derived SMC was reported using the Cheung protocol [99]. Herein, the initial differentiation stage (day $0-5$ or day $0-7$ ) begins with the induction of three intermediate lineages: neuroectoderm (NE), lateral plate mesoderm (LM) and paraxial mesoderm (PM) [95]. Early mesoderm differentiation was started with a combination of chemically defined medium (CDM), containing polyvinyl alcohol (PVA), FGF2, the strong inhibitor of phosphoinositide 3-kinases (PI3K) LY294002, and BMP4 for 1.5 days. Consequently, either LM differentiation was 
started in CDM-PVA medium with FGF2 and BMP4 for 3.5 days or PM differentiation in CDM-PVA medium with FGF2 and LY294002 for 3.5 days. To induce NE differentiation, cells were cultured in CDM-PVA medium with FGF and the potent inhibitor of the TGF- $\beta /$ Activin/Nodal pathway that inhibits ALK5 (SB431542) for 7 days. Successfully intermediate lineage differentiation was confirmed by the presence of the characteristic markers (PAX6, Nestin, GBX2 for NE; KDR, NKX2-5, ISL1 for LM; TCF15, TBX6, MEOX for PM) and was followed by SMC differentiation: LM-, PM- and NE-cells were re-suspended as single cells in CDM-PVA medium containing PDGF-BB and TGF $\beta 1$ for 6 days. The cellular markers generally expressed by mature SMC Transgelin (Tagln/SM22 $\alpha$ ), calponin (CNN1), and smooth muscle myosin heavy chain (MYH11) as well as the exhibited well-defined fibrous morphology especially in mature SMC confirmed the generation of functionally distinct SMC $[95,100]$.

The differentiation of human iPSCs towards SMC through the mesoderm in general was investigated by Patsch et al. who showed that selective GSK3 inhibitors combined with BMP4 efficiently activated WNT signaling which in turn directed differentiation of iPSCs into mesoderm as described above for iPSC-derived endothelial cells [50]. The authors demonstrated that replacing endothelial-inductive cues with factors that promote SMC formation (Activin A and PDGF-BB) efficiently generated SMC. Thus, Activin A and/or PDGF-BB were added following mesoderm induction. This modification resulted in the formation of almost exclusively CD140b/PDGFRB-positive SMC with virtually no VE-Cadherin-positive endothelial cells detectable, when Activin A and PDGF-BB were used. These iPSC-derived SMC cultures were nearly homogeneous they required no further purification [50].

Collectively, these data demonstrate that SMC can be efficiently differentiated from human iPSCs, and that reliable protocols exist to generate SMC developmental originspecific. Patient-specific SMC might facilitate the study of disease mechanisms and development of novel therapeutic interventions.

\section{Cell culture limitations}

Although endothelial cells as well as SMC could be isolated simultaneously from small vessel biopsies and expanded in culture, the quality of the cells after expansion is still not clear and primary isolates were prominently characterized by a very limited proliferation potential [101-103]. Although a genetic manipulation of endothelial cells and SMC by the introduction of human telomerase reverse transcriptase subunit resulted in prolonged proliferation potential while characteristics of normal control cells were retained, safety of the cells after genetic manipulation is still a great concern $[104,105]$. Human iPSCs-derived vascular wall cells might be the promising way to solve the cell proliferation problem.

However, Li et al. performed a functional characterization of human iPSCs (derived from IMR90 fetal fibroblasts) and embryonic stem cell (H9)-derived endothelial cells and reported that iPSC-derived endothelial cells proliferated at a lower rate than endothelial cells differentiated from embryonic stem cell [106]. Herein, iPSC-derived endothelial cells were characterized by a lower G2/M phase population and a downregulation endothelial marker proteins upon prolonged culture, indicating that CD31-expressing endothelial cells from human iPSCs cannot be readily expanded in vitro, although the vasculogenic potential was not affected. A global gene and miRNA profiling of human iPSC- and embryonic stem cell-derived endothelial cells demonstrated a high degree of similarity between the generated endothelial cells, in particular as compared to human umbilical vein endothelial cells, although miRNA profiles were significantly different in respective iPSCs and embryonic stem cells [107]. However, epigenetic instabilities and/or phenotypic switches (e.g. spontaneous endothelial-to-mesenchymal transition) after prolonged culture might occur because the endothelial identity may not be well inherited in human iPSCs- and embryonic stem cells-derived endothelial cells [58, 106, 108]. Human iPSCderived hemangioblasts, endothelial cells, and hematopoietic cells were already shown to bear similar phenotypic and morphologic characteristics to those derived from embryonic stem cells, but generation of respective cells was less efficient [109]. Prolonged culturing further demonstrated severely limited growth and expansion capabilities, early cellular senescence and significantly increased apoptosis in iPSC-derived vascular cells. The latter ones could not be observed in iPSC-derived endothelial cells investigated by $\mathrm{Li}$ et al., which might be due to the different differentiation methods that were used [106, 109]. Moreover, the observed differences might be based in the different cellular origins used for iPSC generation, because some reports already revealed that a somatic memory does exist [110-112]. In line with this hypothesis, it was also shown that the cellular origin influences the lineage differentiation propensity of human iPSCs [113]. Endothelial cells differentiated from iPSCs derived from three types of somatic cells (fibroblasts, endothelial cells and cardiac progenitor cells) of the same individuals showed clear differences in the endothelial cell differentiation propensity and gene expression of endothelial-specific markers. In vitro and in vivo endothelial cells differentiated from endothelial cell-derived iPSC maintained a higher CD31-positive population upon long-term culturing and showed higher recovery rates than those derived from fibroblasts and cardiac progenitor cells [113]. 
Thus, the somatic memory of iPSCs should be carefully considered before clinical translation. Furthermore, improvements in the long-term culture are needed to facilitate the clinical application of human iPSC-derived vascular cells and in particular endothelial cells in the future.

\section{Applications}

iPSCs are capable of self-renewal and differentiation into any cell type in the human body, and thus are attractive resources to generate unlimited numbers of vascular cells. Many groups have shown that vascular cells and in particular endothelial cells and SMC could be reproducibly derived from human iPSCs. Human iPSC-derived vascular cells have become of interest as patient-specific therapeutic tools. The respective mechanistic studies may gain knowledge that aim in understanding the pathogenesis of vascular disease, foster developing interventions and therapeutics as well as enabling drug screening applications. The in vitro vascular cell differentiation from iPSCs also provides a new opportunity to study molecular mechanisms that control endothelial cell or SMC fate. These cells represent a potentially valuable tool and for regenerative therapies, e.g. cell replacement to re-vascularize ischemic areas and the development of robust and reproducible vascular tissues (stem cell-based vascular engineering).

\section{Patient-derived vascular cells: unraveling mechanisms and disease modeling}

Abnormal proliferation of vascular SMC can lead to narrowing or blockage of the ascending aorta and other arterial vessels. This disease pattern is characteristic for supravalvular aortic stenosis (SVAS) which is caused by mutations in the elastin gene [89]. Using a modified EB-initiated differentiation method (for protocol see above) to generate SMC from human iPSCs reprogrammed from foreskin fibroblasts and from epicardial coronary arteries SMC of patients with SVAS, the authors validated that SMC derived from SVAS iPSCs have the prototypical hyper-proliferation response seen in primary SMC from SVAS patients. Furthermore, novel evidence was provided that ERK1/2 signaling is activated in SVAS iPSC-SMC and accounted for their hyperproliferation, which suggested that inhibition of cellular proliferation by decreasing ERK1/2 signaling might be potential therapeutic strategies in SVAS patients [89]. Conclusively, SVAS iPSC-SMC recapitulated key pathological features of patients with SVAS and may provide a promising strategy to study disease mechanisms and to develop novel therapies. In a further study using SMC differentiated from SVASiPSCs the authors nicely showed that these that in line with the increased migration potential, these SVAS iPSC-SMC have robustly up-regulated expression of integrin- $\beta 3$ protein, strongly indicating that enhanced integrin- $\beta 3$ signaling builds a crucial link between elastin deficiency and arterial hyper-muscularization. Thus, $\beta 3$-blockade is a promising and much needed noninvasive therapeutic approach for SVAS [114].

As it is already known that vascular SMC subtypes show lineage-specific differences in growth, gene expression, and functional properties, and that these differences may contribute to site-specific patterns of vascular diseases (such as aortic aneurysm), the progress in defining protocols for generating human SMC subtypes of distinct embryonic origins already contributed to dissect cell-type specific molecular mechanisms. Human iPSC-derived embryonic lineagespecific SMC were used to gain insight into the molecular mechanisms involved in SMC development. NOTCH3 signaling emerges as one of the key regulators of vascular SMC differentiation and maturation in vitro and in vivo in a lineage- and temporal-dependent manner [81]. The authors followed the Cheung protocol and used SMC differentiated from the three intermediate populations (neural crest, lateral and paraxial mesoderm) of human iPSCs and profiled the expression of NOTCH receptors, ligands, and downstream elements during the development of origin-specific SMC subtypes. NOTCH3 was the only NOTCH receptor to show lineage-specific expression changes during SMC development. In addition, NOTCH3 and its ligand, JAG1, share a similar expression trend in developing and mature SMC [81].

Bargehr et al. investigated the respective potential of different embryonic origin-specific SMC derived from human embryonic stem cells to support endothelial network formation in vitro using their previously generated Cheung protocol of lineage-specific SMC [115]. Lateral mesodermderived SMC were shown to support endothelial network complexity and survival in three-dimensional co-culture via increased expression of Midkine/neurite growth-promoting factor 2 as one important mediator for the enhanced vasculogenic potency, further highlighting a lineage-specific approach being beneficial for vascular tissue engineering and therapeutic revascularization [115].

Understanding the regulatory mechanisms that control SMC differentiation from vascular progenitors with respect to their developmental origin is essential for exploring therapeutic targets for potential clinical applications because differences in embryological origins between SMC could contribute to site-specific localization of vascular diseases $[80,82,100,116]$. The recent advancement of iPSCs and lineage-specific SMC differentiation technology now provides unique methods to investigate human SMC subtypes of distinct embryonic origins on the spatial specificity of vascular disease. For example, the aortic root, ascending aorta 
and aortic arch were shown to be populated by SMC arising from neural crest, while the descending aorta is populated by SMC from the paraxial mesoderm. Jiao et al. used the Cheung protocol to investigate whether the aortopathy in patients with congenital cardiovascular malformation (bicuspid aortic valves, BAV) is due to a defective differentiation of neural crest stem cells to SMC that spares the paraxial mesoderm cells-derived SMC. It is known that aneurysms associated with BAV most commonly involve the aortic root, aortic arch, and ascending aorta while spare the descending aorta [96]. Interestingly, neural crest-derived SMC generated from iPSCs (reprogrammed from PBMC) from patients bearing $\mathrm{BAV} /$ thoracic aortic aneurysms and not paraxial mesoderm-derived SMC were shown to contribute to the aortopathy associated with BAV because these cells showed a decreased differentiation and contraction potential [96].

The growth and reactivity of SMC were influenced and controlled by the underlying endothelial cells that comprise a permeable tissue layer, which controls the interaction of the vessel wall with circulating blood components, and regulates the vascular response to hemodynamic forces. Collado et al. speculated that iPSC-derived endothelial cells and SMC represent an immature phenotype because these cells were not derived from an intact blood vessel [99]. Because hemodynamics and heterotypic cell-cell communication play important roles in vascular cell phenotypic modulation the authors co-cultured iPSC-derived endothelial cells and SMC under vascular region-specific blood flow hemodynamics, and compared these hemodynamic co-cultures with adult blood vessel-derived endothelial and SMC. Their studies revealed that the hemodynamic co-culture restored a high degree of similarity in their responses to pathological stimuli which were associated with vascular diseases (e.g. atheroprone hemodynamics which promote inflammation, monocyte transmigration, differentiation and ensuing atherosclerosis) [99]. Thus, iPSC-derived vascular cells exposed to hemodynamics may provide a more-realistic viable system for modeling rare vascular diseases and testing new therapeutic approaches. Belair et al. used iPSC-derived endothelial cells in combination with the well known angiogenic tube formation assay on Matrigel (3D vascular network formation) to quantitatively assess capillary-like structures in response to growth factor stimulation and pharmacological inhibition [117]. This combination demonstrated the feasibility of using a well-defined, stable source of iPSCderived endothelial cells to model blood vessel formation within a variety of contexts formats that enables basic biological research and molecular pharmacology studies with the potential to generate donor specific disease models.

Human iPSC-derived endothelial cells cultured in peptide-functionalized poly(ethylene glycol) (PEG) hydrogels, either on standard well plates or within a passive pumping polydimethylsiloxane tri-channel microfluidic device were further shown to offer a defined platform for investigating vascular morphogenesis in vitro using both standard and microfluidic formats [118]. These PEG hydrogels contained incorporated matrix metalloproteinase (MMP)-degradable crosslinks and the synthetic peptide Gly-Arg-Gly-Asp-Ser (GRGDS) (which corresponds to a fragment of fibronectin and contains its cell adhesion sequence RGD) that caused degranulation and spreading of monolayers cells. The authors showed that iPSC-derived endothelial cells selfassembled into vascular networks through physiologically relevant mechanisms when cultured in these PEG hydrogels, and capillary tubules with lumens were stable for at least 2 weeks when the hydrogels were polymerized within the microfluidic device. These results again demonstrated the value of engineering approaches for extending the stability of in vitro vascular networks to form robust and reproducible vascular tissues using iPSC-derived endothelial cell monocultures for disease modeling and screening applications [118].

Concerning the stability of developing 3D microvascular networks, which were build up of endothelial cells, Kurokawa et al. confirmed that human iPSCs-derived endothelial cells formed stable, perusable micro-vessels when cultured within 3D microfluidic devices [119]. Again, it was shown that iPSCs-derived endothelial cells comprise similar physiological functions characteristic of primary endothelial cells in a series of in vitro assays including permeability, response to shear stress, and the expression of endothelial markers with reproducibility. Thus, micro-physiological systems (or organ-on-a-chip) platforms in combination with iPSCsderived endothelial cells were well suited to recapitulate in vivo physiology using small-scale in vitro tissue models of human physiology.

Human iPSC-derived endothelial cells from three families with familial pulmonary arterial hypertension (FPAH) patients, where the autosomal dominant disease-causing BMPR2 mutation is only $20 \%$ penetrant, unaffected mutation carriers, and gender-matched controls were compared to investigate modifiers of BMPR2 signaling [120]. FPAH patient derived iPSC-endothelial cells showed reduced adhesion, survival, migration, and angiogenesis compared to the cells derived from unaffected mutation carriers or from controls. Protective BMPR2 modifiers were shown to preserve pP38 signaling and adhesion in iPSC-derived endothelial cells of unaffected mutation carriers, identified BIRC3 (an inhibitor of apoptosis) and correlated increased BIRC3 expression levels to normalization of EC survival. Finally, the correction of the BMPR2 mutation in FPAH patient derived iPSC-endothelial cells restored signaling and EC function, which suggested that identified protective modifiers for FPAH that could help to inform the development of future treatment strategies [120]. 
Tseng et al. differentiated endothelial cells from human iPSCs which were reprogrammed from peripheral blood cells of patients with Fabry disease to investigate specifically the accumulation of globotriaosylceramide (GB3) in endothelial cells, which is considered to be pathogenically responsible for the phenotype variability of the disease that causes cardiovascular dysfunction [121]. Fabry disease is an X-linked inherited lysosomal storage disease caused by $\alpha$-galactosidase A (GLA) deficiency resulting in the accumulation of GB3 in a variety of tissues, but recent attention shifted towards studying the mechanisms through which Gb3 accumulation in vascular cells leads to endothelial dysfunction and eventually multi-organ failure, while the underlying mechanism remains elusive. Using endothelial cells derived from iPSCs Fabry diseased patients in comparison to healthy control iPSC-derived endothelial cells, the authors identified superoxide dismutase 2 , a mitochondrial antioxidant, to be significantly downregulated in the patient-derived endothelial cells. Together with an increased production of reactive oxygen species (ROS) and a significantly enhanced AMPK activity, finally vascular endothelial dysfunction was caused, suggesting dysregulated mitochondrial ROS may be a potential target for treating Fabry disease in particularly for severe Fabry disease-associated cardiovascular complications [121]. Using endothelial cells differentiated from mesoderm-induced human iPSCs Harding et al. revealed that all three MAPK (ERK, P38, and JNK) and the PI3K pathways are responsible for the induction of endothelial cell fate [68]. Furthermore, their generated homogeneous endothelial cells could be engrafted and generated functional vasculature in normal and ischemic environments in vivo. Conclusively the authors provided evidence that iPSC-derived endothelial cell have great potential to treat a vascular disease in particular with respect to the development of cell therapy to treat ischemia.

Reprogrammed skin fibroblasts from two Hutchinson-Gilford Progeria syndrome (HGPS) patients and two healthy HGPS parents were differentiated to vascular cells to investigate the impact of the substance progerin on the functional properties of the different cell types [122]. HGPS is caused by progerin (a truncated and farnesylated form of Lamin A) and affects mesenchymal lineages, including the skeletal system, dermis, and vascular SMC. Using HGPSiPSC-derived SMC the authors identified cytosolic heterogeneously sized, calponin-positive inclusion bodies in the cytoplasm that affected the contractile properties of the SMC in situ. As autopsies already indicated that HGPS-related death is associated with premature atherosclerosis which may be accompanied by vascular SMC loss, the authors further reported a pronounced sensitivity of the HGPS-SMC to various imposed insults (hypoxia, combination of hypoxia and substratum deprivation, repeated pulses of electrical stimulation). This work was not only one of the first reports of an iPSC-based disease model of HGPS, together with the revealed perturbation of contractile properties due to calponin sequestration, this lineage may feature prominently in the pathology of progeria [122].

Another model to dissect the molecular mechanisms of a certain disease and thereby allowing to identify novel targets for treatment and to provide an innovative human platform for the testing of new drugs is the iPSC-derived vascular model of Marfan syndrome that was used to identify key mediators of SMC death [97]. The authors followed the Cheung protocol to generate embryonic lineage-specific SMC which enabled them to recapitulate the pathology seen in Marfan aortas, including defects in fibrillin-1 (FBN1) accumulation, ECM degradation, TGF $\beta$ signaling, contraction and apoptosis finally resulting in aortic aneurysms in Marfan syndrome patients. Within these model Granata et al. highlighted the role for $\mathrm{p} 38$ MAP kinase in regulating SMC apoptosis and proliferation and identified KLF4 as a potential contributing factor to Marfan syndrome pathology. The detected abnormalities, like upregulation of both P-p38 and KLF4 observed in the iPSC-derived SMC as well as the detected high TGF $\beta$ levels were further corrected by CRISPR-based editing of the FBN1 mutation [97]. The authors even validated their findings in patient samples, and thus confirmed that the in vitro system accurately modeled the human Marfan disease. Thus, this work further proved the use of iPSCs as model cells representing a tool to dissect molecular and mechanosensing mechanisms of certain diseases and thereby including the ability to identify novel targets for potential treatments, as well as a resourceful platform for testing new drugs.

\section{Drug screening}

iPSC-derived modeling systems offer a dual capacity for investigators because they cannot only offer a platform for gaining valuable insights into the mechanisms of disease progression but can also be used as a tool for drug screening to treat the disease $[6,99]$.

Patient-derived iPSCs were already used as potential source for studying anti-hypertensive drug response [123]. Therefore, multiple iPSC lines generated from PBMCs isolated from hypertension patients were established and vascular SMC were differentiated via EB-generated mesenchymal intermediates in the presence of SMC-specific factors for 10 days. The contractility of the generated and FACS-sorted (CD140b/PDGFRB- and CD91/LRP1-positive) SMC and the inflammatory signaling was investigated in response to different chemical (Phorbol 12-myristate 13-acetate, PMA) or physiological stimuli (endothelin-1) was analyzed, and nicely showed that all iPSC-SMC lines contracted and 
tremendously responded to different inflammatory stimuli [123]. With respect to hypertension, pharmacogenomics studies seek to identify genetic sources of variable antihypertensive drug response. Up to now this study did not unravel potential relationships between drug responses and genetic associations, namely single-nucleotide polymorphisms, but these investigations using vascular cells generated with iPSC technology paved the way for providing a great interface to bring patient cells with their genomic data into the laboratory and to study hypertensive responses [123].

A platform based on endothelial cells derived from iPSCs generated from human cord blood was established for drug screening from Vazao et al., which may open new avenues of research for the study and modulation specifically of the embryonic vasculature [124]. Herein, generated iPSCs were differentiated into embryonic endothelial cells, allowed to mature under flow conditions for more accurate toxicological assessment prior exposing the cells in static conditions to a Library of Pharmacologically Active Compounds (LOPAC, from Sigma). The library consisted of 1280 pharmacologically active compounds, which were inhibitors, receptor ligands, pharma-developed tools, and approved drugs that impacts most signaling pathways and covers all major drug target classes. Interestingly, two compounds that had higher inhibitory effect in embryonic than postnatal endothelial cells were identified: fluphenazine (an antipsychotic), which inhibits calmodulin kinase II and pyrrolopyrimidine (an anti-inflammatory agent), which inhibits VEGFR2, decreases endothelial cell viability, induces an inflammatory response, and disrupts preformed vascular networks. The vascular effect of the pyrrolopyrimidine was further validated in embryonic and adult zebrafish [124]. As the vascular system is the first functional organ to develop in the mammalian embryo, and the disruption of the vascular system has been correlated with fetal loss, human malformations, and cognitive impairment, these generated platform is important for the identification of compounds with developmental toxicity. Conclusively the authors achieved a huge effort in generating a valid alternative to animal testing that be used to screen existing and newly developed drugs.

Up to now, patient-specific iPSCs have become an important tool for investigating and modeling human diseases, as well as for screening drugs.

\section{Treatments/vascular grafts}

The blood vessel system is a dense vascular network that forms the transport routes for nutrients, oxygen, hormones and much more simultaneously disposes of toxic waste from the body. However, as soon as something in the vessels is not correct, so that we suffer from vascular disease, the affected person quickly notices signs of illness or failure. Thus, the blood vessels play a decisive role when it comes to the functional and viability of all organs and organs. Like all other organs, the blood vessels are not indefinitely resistant to all external and internal influences. Especially in the present time, diseases of the blood vessel system are increasing to an astonishing extent. Disorders of the blood vessels and the heart are grouped as cardiovascular diseases [125, 126]. Cardiovascular diseases remain the leading cause of death in the world, accounting for 17.7 million premature deaths (under the age of 70) per year worldwide in 2015, representing $31 \%$ of all global deaths [127]. Depending on the anatomical region of involved blood vessels, cardiovascular diseases include coronary heart disease (blood vessels supplying the heart muscle), cerebrovascular disease (blood vessels supplying the brain), peripheral arterial disease (blood vessels supplying the arms and legs) and deep vein thrombosis and pulmonary embolism (blood clots in the leg veins, which can dislodge and move to the lungs) [125, 126].

The current standard of care to treat patients which suffer from coronary heart disease in the need of conduit vessels and bypass grafts is the use of autologous donor vessels as vascular grafts [127-129]. However, availability of healthy autologous vessels is often limited from these patients, which is mainly based to existing endothelial dysfunction [128, 130, 131]. In addition, recruitment of monocytes causing neointimal hyperplasia can be induced resulting from damage to the delicate endothelium during vascular invention [132, 133]. Also mechanical integrity of these vascular scaffolds might be impaired, possibly due to a lack of mature SMC, and the addition of SMC has been shown to regulate endothelial cell function by increasing expression of angiogenic factors [134-136]. Although commercial polymeric bypass grafts based on synthetic materials such as polytetrafluoroethylene or polyurethane are a suitable alternative for patients who lack suitable donor vessels, they do not support long-term patency as a small-diameter vascular graft [130, 137-139]. Thus, the ultimate goal of vascular tissue engineering is to develop cell-based small-diameter vascular grafts that resist thrombosis and support graft patency by generating biologically based vascular grafts that exhibit the biological and mechanical properties of native arteries $[139,140]$.

Samuel et al. generated functionally competent and durable engineered blood vessels from human iPSC-derived endothelial cells [141]. The authors investigated the vasculogenic capacity of endothelial cells derived from several reprogrammed fibroblasts (human adult dermal fibroblast cell line HFib2-iPS4, HFib2-iPS5, human foreskin fibroblast cell line HS27-iPSC, and human foreskin fibroblast cell line BJ-iPSC cells) which were purified by flow cytometry sorting using combinations of anti-CD34, KDR, and NRP1 antibodies. In combination, a model of durable blood 
vessel formation in vivo in mice using the murine embryonic precursor cell line 10T1/2 as supporting perivascular cells was used [142]. Generated endothelial cells from all iPSCs formed stable functional blood vessels in vivo, lasting for around 280 days in mice [141]. Furthermore, the authors successfully generated functional blood vessels in vivo using endothelial cells derived from three different iPSC lines reprogrammed from fibroblasts of type-1 diabetic patients. Beside the well-known metabolic impairments, diabetes is characterized by a prominent endothelial dysfunction (e.g. augmented vasoconstriction, increased inflammation and thrombosis) of many vascular beds, directly affecting wound healing processes in diabetic patients [143, 144]. Therefore, diabetes is considered as a vascular disease and a therapeutically improvement of endothelial dysfunction is a major issue in the prevention of vascular complications associated with all forms of diabetes mellitus [143, 145, 146]. Beside the potential of an autologous therapy approach using reprogramed iPSCs-derived vascular cells with reversed stress effects of high glucose caused by diabetes, the generation of vasculatures holds great promise in treating diabetic patients with vascular and wound healing complications. Supporting evidence was already investigated by Chan et al., who differentiated early vascular cells from type 1 diabetes mellitus (T1D) patient-derived hiPSCs, generated vascular networks of the respective matured endothelial cells in deliverable hydrogels and further demonstrated the integration into host vasculature networks in vivo [147]. Herein, vascular endothelial cadherin-positive cells (early endothelial cells) and platelet-derived growth factor $\beta$-positive cells (early pericytes) were differentiated from the T1D-derived iPSC cell lines T1D H2.1 and T1D 1018S, as well as from the healthy control donor cell line $\mathrm{BC} 1$ using high VEGF media treatment after mesodermal induction in iPSCs plated onto collagen IV coated plates. Upon maturation T1D-iPSC-derived early endothelial cells expressed mature endothelial markers and displayed behaviors typical of mature and functional endothelial cells, in contrast to T1D-derived endothelial (progenitor) cells that beside an overall reduction in the amount are characterized by an prominent dysfunctionality [148-150]. Functionality of T1D-iPSC-derived endothelial cells was further confirmed in response to hypoxia, which again highlights the potential of these cells as a therapeutic tool to treat diabetic vascular complications by the delivery of a microvascular bed e.g. in a hydrogel matrix [52, 147, 151]. Thus, this work points out nicely that patient-specific iPSC-derived vascular cells might provide a unique opportunity to advance autologous therapy for diabetic-vascular complications, in particular for diabetic wound healing.

As it is known that type-1 diabetic is associated with dysfunctional endothelial cells, capability to generate large amounts of functional endothelial cells from patients for autologous cell transplantation or tissue-engineering strategies is highly appealing for many diseases where re-vascularization is required $[141,152]$. Hu et al. used SMC differentiated in the presence of TGF $\beta 1$ and PDGFBB from of integration-free reprogrammed iPSCs out of human PBMCs for vascular tissue regeneration [153]. Generated SMC were successfully seeded on 3D macroporous nanofibrous poly(L-lactide) scaffolds, which had been coated with fibronectin prior subcutaneous implantation in immuno-deficient mice. Histological analysis of the implants after 14 days revealed that implants showed uniform cell growth inside the entire scaffold and significant collagenous matrix deposition, while no teratoma tissue formation was observed. Collectively this study had established an efficient patient-specific approach using iPSC-derived vascular cells towards in vivo regeneration of vascular tissue [153].

In 2015 already Ren et al. greatly reported the improved regeneration of functional pulmonary vasculature by repopulating the vascular compartment of decellularized rat and human lung scaffolds with human iPSC-derived endothelial cells and SMC [140]. Initially the authors successfully established transplantable rat lung grafts by delivering epithelial and endothelial cells, namely human umbilical cord venous endothelial cells into vascular and airway compartments of decellularized rat lung scaffolds [154]. However, the in vivo graft function declined within hours after transplantation, with substantial pulmonary secretions and the development of graft edema. These deficiencies were due in part to poor vascular performance of the engineered lungs. Endothelial coverage of scaffold vessels turned out being incomplete, which promotes blood clotting and hemorrhage [140, 154, 155]. When Ren et al. scaled their approach to the human lung lobe in combination with iPSC-derived endothelial cells, an efficient cell delivery, maintenance of cell viability and establishment of perfusable vascular lumens was achieved [140]. With respect to the aim of using autologous cells for clinical applications, the authors successfully regenerated lungs with vascular cells derived from human iPSCs that re-established of a functional vascular lumen across the entire graft with mature barrier function and sustained capillary perfusability.

Obtaining vascular SMC with robust, mature, elastic fibers is a key obstacle in tissue-engineered blood vessels. Eoh et al., followed the Wanjare protocol to differentiate SMC from human iPSCs and placed these cells on scaffolds in a pulsatile flow bioreactor, resulting in vascular smooth muscle tissue with robust elastic fibers and enhanced functionality [156]. Human iPSCs were dissociated and cultured on collagen type-IV-coated dishes in differentiation media (alpha-MEM with 10\% FBS) for 6 days prior re-plating in differentiation media supplemented with TGF $\beta 1$ and PDGF$\mathrm{BB}$ for additional 6 days. Differentiated smooth muscle-like cells were then seeded onto PEGdma-PLA [poly(ethylene glycol) dimethacrylate/poly(L-lactide)] scaffolds in quiescent 
media (containing TGF $\beta 1$ and $0.5 \%$ FCS) and either incubated under static conditions or subjected to peristaltic flow in a bioreactor system for the remainder of the differentiation (day 30) [156]. As SMC of the tunica media produce a complex ECM comprised of both elastin and collagen, which dictate the mechanical properties of blood vessels, significantly increased expression levels of ECM components (elastin, fibronectin, collagen I) were detected iPSCsmooth muscle tissue cultured in the bioreactor, which had further an increased calcium signaling and contraction in comparison to the static control. Thus, the authors presented an effective approach to engineer elastic functional vascular smooth muscle tissue for tissue engineering and regenerative medicine applications [156].

A straight forward approach concerning the clinical utility of iPSC-derived vascular cells was recently, reported by Lee et al. who enriched human iPSC-derived endothelial cells via a clinically compatible system [157]. Herein, a couple of human pluripotent stem cell lines (H1, H7, and $\mathrm{H} 9$ embryonic cells as well as BJ1 and PGP1 iPSCs) cultured in mTeSRTM 1 on Matrigel were differentiated towards the mesodermal lineage using CHIR99021. After 4 days endothelial cell differentiation was induced using medium containing VEGF-A, FGF2, EGF, DLL4, and heparin for additional 5-9 days. An additional treatment of the respective cultures with the Notch ligand, DLL4, further increased the cell numbers of cells expressing the endothelial marker KDR/VEGFR2/FLK1. Cells were purified then using MACS technology in combination with CDH5/CD144/VE-Cadherin expression and successfully implanted in an animal model of hindlimb ischemia. To finally enhance cell survival, vesselformation, and the therapeutic potential generated cells were by encapsulated with a biocompatible peptide amphiphile (PA) nanomatrix gel prior to implantation. Corroboratively, the PA nanomatrix encapsulated iPSC-derived endothelial cells showed better perfusion recovery, more robust and longer cell survival, and higher and prolonged angiogenic and vascular incorporation capabilities for tissue ischemia after 10 month than the group which received the same cells without the matrix [157]. With respect to the critical importance for a clinical applicability, this work demonstrated nicely that (1) endothelial cells could be differentiated from human iPSCs under defined conditions free of xenogeneic components, (2) endothelial cells were yielded at high efficiency, (3) the procedure was verified in multiple cell lines, and (4) the therapeutic effect and safety (no teratoma formation) was verified in animal models of ischemic vascular disease.

\section{Vascularization strategies for other tissues}

Clinical applications for vascular-related diseases (e.g. heart attack caused by atherosclerosis) commonly use the grafting of patients autologous arteries and veins, which are limited and often damaged due to the initial disease or advanced aging [158, 159]. Tissue-engineered replacement vessels represent an ideal solution to this clinical problem [158, 160]. Besides the direct forming of artificial blood vessels, producing tissue constructs with improved supporting vascular networks, as incorporation of a functional vascular network is required for functional regeneration of any tissue (Fig. 3). Thus, the creation of a stimulating microenvironment by the inclusion of vascular cells supports also various other tissue types, including engineered humanized intestinal grafts [161], livers [162, 163], and cardiovascular [164-166] and skeletal muscle tissues [167-170].

The supportive action of an endothelial cell co-culture with the generated cells of interest for organogenesis was already reported [165, 171, 172]. Takebe et al. generated hepatocyte-specific definitive endodermal cells from human iPSCs and cultured these cells than with human umbilical vein endothelial cells (HUVEC) resulting in an iPSCderived organoid, the embryonic liver bud [163, 173]. After transplantation into immune deficient mice the iPSC-derived organ buds became directly connected to the host vasculature and showed the classical features of functional hepatocytes for a couple of weeks [163]. Human umbilical vein endothelial cells were also used to regenerate the endothelium necessary for a perfusable vasculature in engineered humanized intestinal grafts by repopulating de-cellularized rat intestinal matrix with human iPSC-derived intestinal epithelium [161]. Transplantation of these bioengineered intestinal grafts into immunodeficient rats further successfully showed (1) functionality by absorptive characteristics of the perfusable grafts and (2) survival of the bioengineered human intestinal tissue with preservation of basic function of the grafts following long-term heterotopic transplantation in vivo [161]. In line with these findings Valarmathi et al. used human cardiac microvascular endothelial cells together with human iPSC-derived embryonic cardiac myocytes in combination with a 3-D collagen cell carrier to generate an in vitro 3-D functional vascularized cardiac muscle construct [164].

Although non-immunogenic autologous endothelial cells as well as SMC isolated from patients themselves would be the first choice for vessel and/or vascularized tissue engineering, the numbers of cells obtained from small vessel biopsies remain limited and, moreover, these terminally differentiated cells bear a limited proliferation potential. Even the cells isolated from umbilical veins have limited proliferation potential $[102,174]$. Thus, iPSC-derived vascular 


\section{iPSC-derived Vascular Cells}

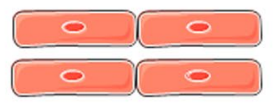

Endothelial Cells

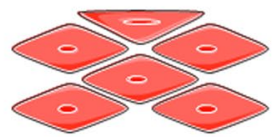

SMC
Vascular Support

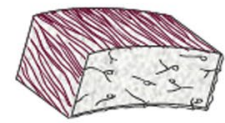

Matrix / Scaffold
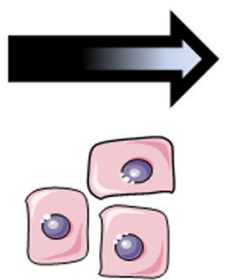

Tissue-specific Cell

\section{Engineered}

Tissue of Interest



\section{Maturation, Functionality, Long-term Plasticity}

Fig. 3 Producing tissue constructs with incorporated supportive vascular networks are required for functional regeneration of any tissue. Tissue engineering/regenerative medicine strategies utilize biocompatible matrices and scaffolds to provide structural support for the tissue-specific cells of interest that have the ability to form tissues in vitro or within the body upon transplantation. These tissue engineering matrices are designed to mimic the naïve situation, and thus to influence the physical, chemical and biological environment surrounding a certain cell population, e.g. hepatocytes, intestinal epithe-

cells are an attractive source of cells that have been explored for the production of blood vessel replacements [175]. Conformingly, Giacomelli et al. generated and characterized human cardiac microtissues in vitro that integrated both cardiomyocytes and endothelial cells co-differentiated from human iPSCs in complex 3D structures after initial cardiac mesoderm induction [176]. This in vitro model was shown to recapitulate nicely the native human physiology because of its incorporated cardiomyocyte-endothelium crosstalk finally resulting in beating 3D structures 7 and 20 after initial aggregation and thus representing an advanced human stem cell-based platform for cardiovascular disease modeling and/or testing of relevant drugs [176]. Masumoto et al. successfully generated a novel 3D engineered cardiac tissue composed of human iPSC-derived cardiomyocytes, vascular endothelial cells, and mural cells that displayed excellent in vitro structural maturation and electromechanical performance translation [177]. Furthermore, implantation of these engineered cardiac tissues in an immune tolerant rat myocardial infarction model resulted in a proper regenerated myocardium at 4 weeks after implantation, demonstrating that the iPSC-derived engineered tissue comprised of cardiomyocytes and vascular cells were capable of in vivo lial cells, skeletal or cardio-myocytes. Concerning oxygen diffusion and nutrient perfusion it is desired that a tissue is prevascularized before implantation, because generally the diffusion limitation allows only cells within 1-2 mm from the nearest capillary to survive. Coculturing and integration of supporting vascular cells was further shown to improve maturation and functionality of the tissue-specific cells of interest, finally resulting in a better engraftment upon in vivo implantation

survival, remodeling, and perfusion post-implantation with a chimeric composition of both host and graft-derived vasculature [177].

The integration of supporting vascular cells was further shown to improve maturation and functionality of engineered skeletal muscle tissue, finally resulting in a better engraftment upon in vivo implantation [167-170]. Criswell et al. showed that the addition of endothelial cells enhanced vascularization, innervation and muscle tissue formation when implanted muscle progenitor cells formed mature striated muscle fibers [168]. This effect was most likely related to VEGF because endothelial cell-derived VEGF secretion resulted in muscle progenitor cells migration and protection from apoptosis [168, 178, 179].

\section{Concluding remarks}

The therapeutic potential of human iPSCs is quite promising as they are patient-specific stem cells that could be derived from easily accessible sources of tissue-such as the donor's skin or peripheral blood-and that do not face the immunological barrier or ethical concern which confront 
cells derived from human embryonic stem cells. With the appropriate differentiation protocols, iPSCs could then be used to generate vascular cells. Thus, the central advantages of iPSC-derived endothelial cells and SMC are their potential abundance by generating nearly unlimited numbers and their immune-privileged status as autologous tissue. Importantly, patient genomic information is maintained during the reprogramming and differentiation processes. Because iPSCs can be derived from subjects with genetic diseases, they represent an ideal vehicle to better understand a variety of diseases including heritable disorders, in particular the molecular mechanisms that dominate in vascular diseases, for screening of novel therapeutics and to foster vascular regeneration by cell replacement therapy or vascular grafts.

Although iPSCs start a new era of regeneration medicine, the tumorigenesis risk might compromise their further clinical applications. In turn, for vascular regeneration already robust selection markers and refined experimental protocols have been established to guide human iPSCs reproducibly to a vascular lineage. Additional negative selection against remaining pluripotent cells could be an additional option, to limit the risk of teratoma formation. Concerning the patientderived autologous iPSC-differentiated cells, the respective genetic background is a benefit for vascular disease modeling studies; but because the same genetic or acquired abnormalities that predisposed a patient to a particular disease will be persist in their iPSCs might result in dysfunctional vascular cells or iPSC and resulting vascular progenies with reduced differentiation capabilities.

However, up to now, iPSC-derived vascular cells provide a reliable model system that enables basic vascular-biological research and molecular pharmacology studies with the potential to generate patient- specific disease models. In addition, the generation of clinically relevant numbers of vascular cells from human iPSC for use as a cell therapy in human subjects is already feasible.

Acknowledgements The Jürgen Manchot Stiftung (Düsseldorf, Germany) supported this work.

\section{Compliance with ethical standards}

Conflict of interest The author states that there are no personal or institutional conflicts of interest.

Open Access This article is distributed under the terms of the Creative Commons Attribution 4.0 International License (http://creativecommons.org/licenses/by/4.0/), which permits unrestricted use, distribution, and reproduction in any medium, provided you give appropriate credit to the original author(s) and the source, provide a link to the Creative Commons license, and indicate if changes were made.

\section{References}

1. Takahashi K, Yamanaka S (2006) Induction of pluripotent stem cells from mouse embryonic and adult fibroblast cultures by defined factors. Cell 126(4):663-676. https://doi.org/10.1016/j. cell.2006.07.024

2. Hirschi KK, Li S, Roy K (2014) Induced pluripotent stem cells for regenerative medicine. Annu Rev Biomed Eng 16:277-294. https://doi.org/10.1146/annurev-bioeng-071813-105108

3. Tani K (2015) Towards the safer clinical translation of human induced pluripotent stem cell-derived cells to regenerative medicine. Mol Ther Methods Clin Dev 2:15032. https://doi. org/10.1038/mtm.2015.32

4. Efthymiou AG, Chen G, Rao M, Chen G, Boehm M (2014) Self-renewal and cell lineage differentiation strategies in human embryonic stem cells and induced pluripotent stem cells. Expert Opin Biol Ther 14(9):1333-1344. https://doi.org/10.1517/1471 2598.2014.922533

5. Ulrich H (2017) Stem cell reviews and reports: induced pluripotent stem cells, embryonic stem cells and development section. Stem cell Rev 13(1):3. https://doi.org/10.1007/ s12015-017-9722-8

6. Scudellari M (2016) How iPS cells changed the world. Nature 534(7607):310-312. https://doi.org/10.1038/534310a

7. Flamme I, Frolich T, Risau W (1997) Molecular mechanisms of vasculogenesis and embryonic angiogenesis. $\mathrm{J}$ Cell Physiol 173(2):206-210. https://doi.org/10.1002/ (SICI)1097-4652(199711)173:2<206:AID-JCP22>3.0.CO;2-C

8. Patan S (2004) Vasculogenesis and angiogenesis. Cancer Treat Res 117:3-32

9. Adams RH, Alitalo K (2007) Molecular regulation of angiogenesis and lymphangiogenesis. Nat Rev Mol Cell Biol 8(6):464-478. https://doi.org/10.1038/nrm2183

10. De Val S, Black BL (2009) Transcriptional control of endothelial cell development. Dev Cell 16(2):180-195. https://doi. org/10.1016/j.devcel.2009.01.014

11. Augustin HG, Koh GY, Thurston G, Alitalo K (2009) Control of vascular morphogenesis and homeostasis through the angiopoietin-tie system. Nat Rev Mol Cell Biol 10(3):165-177. https:// doi.org/10.1038/nrm2639

12. Klein D (2016) Vascular wall-resident multipotent stem cells of mesenchymal nature within the process of vascular remodeling: cellular basis, clinical relevance, and implications for stem cell therapy. Stem cells Int 2016:1905846. https://doi. org/10.1155/2016/1905846

13. Gibbons GH, Dzau VJ (1994) The emerging concept of vascular remodeling. N Engl J Med 330(20):1431-1438. https://doi. org/10.1056/NEJM199405193302008

14. Korshunov VA, Schwartz SM, Berk BC (2007) Vascular remodeling: hemodynamic and biochemical mechanisms underlying Glagov's phenomenon. Arterioscler Thromb Vasc Biol 27(8):1722-1728. https://doi.org/10.1161/ ATVBAHA.106.129254

15. Monahan-Earley R, Dvorak AM, Aird WC (2013) Evolutionary origins of the blood vascular system and endothelium. J Thromb Haemost 11(Suppl 1):46-66. https://doi.org/10.1111/jth.12253

16. Aird WC (2007) Phenotypic heterogeneity of the endothelium: II. Representative vascular beds. Circ Res 100(2):174-190. https:// doi.org/10.1161/01.RES.0000255690.03436.ae

17. Aird WC (2007) Phenotypic heterogeneity of the endothelium: I. Structure, function, and mechanisms. Circ Res 100(2):158-173. https://doi.org/10.1161/01.RES.0000255691.76142.4a

18. Seidelmann SB, Lighthouse JK, Greif DM (2014) Development and pathologies of the arterial wall. Cellular Mol Life Sci 71(11):1977-1999. https://doi.org/10.1007/s00018-013-1478-y 
19. Griese DP, Ehsan A, Melo LG, Kong D, Zhang L, Mann MJ, Pratt RE, Mulligan RC, Dzau VJ (2003) Isolation and transplantation of autologous circulating endothelial cells into denuded vessels and prosthetic grafts: implications for cell-based vascular therapy. Circulation 108(21):2710-2715. https://doi. org/10.1161/01.CIR.0000096490.16596.A6

20. Fadini GP, Agostini C, Avogaro A (2010) Autologous stem cell therapy for peripheral arterial disease meta-analysis and systematic review of the literature. Atherosclerosis 209(1):10-17. https://doi.org/10.1016/j.atherosclerosis.2009.08.033

21. Wang L, Hu J, Sorek CE, Chen EY, Ma PX, Yang B (2016) Fabrication of tissue-engineered vascular grafts with stem cells and stem cell-derived vascular cells. Expert Opin Biol Ther 16(3):317-330. https://doi.org/10.1517/14712598.2016.1118460

22. Weber B, Kehl D, Bleul U, Behr L, Sammut S, Frese L, Ksiazek A, Achermann J, Stranzinger G, Robert J, Sanders B, Sidler M, Brokopp CE, Proulx ST, Frauenfelder T, Schoenauer R, Emmert MY, Falk V, Hoerstrup SP (2016) In vitro fabrication of autologous living tissue-engineered vascular grafts based on prenatally harvested ovine amniotic fluid-derived stem cells. J Tissue Eng Regen Med 10(1):52-70. https://doi.org/10.1002/term.1781

23. Losordo DW, Dimmeler S (2004) Therapeutic angiogenesis and vasculogenesis for ischemic disease: part II: cell-based therapies. Circulation 109(22):2692-2697. https://doi.org/10.1161/01. CIR.0000128596.49339.05

24. Janzen V, Forkert R, Fleming HE, Saito Y, Waring MT, Dombkowski DM, Cheng T, DePinho RA, Sharpless NE, Scadden DT (2006) Stem-cell ageing modified by the cyclin-dependent kinase inhibitor p16INK4a. Nature 443(7110):421-426. https:// doi.org/10.1038/nature05159

25. Mimeault M, Batra SK (2009) Recent insights into the molecular mechanisms involved in aging and the malignant transformation of adult stem/progenitor cells and their therapeutic implications. Ageing Res Rev 8(2):94-112. https://doi.org/10.1016/j. arr.2008.12.001

26. Steens J, Zuk M, Benchellal M, Bornemann L, Teichweyde N, Hess J, Unger K, Gorgens A, Klump H, Klein D (2017) In vitro generation of vascular wall-resident multipotent stem cells of mesenchymal nature from murine induced pluripotent stem cells. Stem cell Rep 8(4):919-932. https://doi.org/10.1016/j. stemcr.2017.03.001

27. Jung Y, Bauer G, Nolta JA (2012) Concise review: induced pluripotent stem cell-derived mesenchymal stem cells: progress toward safe clinical products. Stem Cells 30(1):42-47. https:// doi.org/10.1002/stem.727

28. Kimbrel EA, Kouris NA, Yavanian GJ, Chu J, Qin Y, Chan A, Singh RP, McCurdy D, Gordon L, Levinson RD, Lanza R (2014) Mesenchymal stem cell population derived from human pluripotent stem cells displays potent immunomodulatory and therapeutic properties. Stem Cells Dev 23(14):1611-1624. https://doi. org/10.1089/scd.2013.0554

29. Ma T, Xie M, Laurent T, Ding S (2013) Progress in the reprogramming of somatic cells. Circ Res 112(3):562-574. https://doi. org/10.1161/CIRCRESAHA.111.249235

30. Okano H, Nakamura M, Yoshida K, Okada Y, Tsuji O, Nori S, Ikeda E, Yamanaka S, Miura K (2013) Steps toward safe cell therapy using induced pluripotent stem cells. Circ Res 112(3):523533. https://doi.org/10.1161/CIRCRESAHA.111.256149

31. Dash BC, Jiang Z, Suh C, Qyang Y (2015) Induced pluripotent stem cell-derived vascular smooth muscle cells: methods and application. Biochem J 465(2):185-194. https://doi.org/10.1042/ BJ20141078

32. Lee S, Kim JE, Johnson BA, Andukuri A, Yoon YS (2017) Direct reprogramming into endothelial cells: a new source for vascular regeneration. Regen Med. https://doi.org/10.2217/ rme-2017-0022
33. Yamashita J, Itoh $\mathrm{H}$, Hirashima M, Ogawa M, Nishikawa S, Yurugi T, Naito M, Nakao K, Nishikawa S (2000) Flk1-positive cells derived from embryonic stem cells serve as vascular progenitors. Nature 408(6808):92-96. https://doi.org/10.1038/35040568

34. Oshimori N, Fuchs E (2012) The harmonies played by TGF-beta in stem cell biology. Cell Stem Cell 11(6):751-764. https://doi. org/10.1016/j.stem.2012.11.001

35. Oshimori N, Fuchs E (2012) Paracrine TGF-beta signaling counterbalances BMP-mediated repression in hair follicle stem cell activation. Cell Stem Cell 10(1):63-75. https://doi.org/10.1016/j. stem.2011.11.005

36. Pang K, Ryan JF, Baxevanis AD, Martindale MQ (2011) Evolution of the TGF-beta signaling pathway and its potential role in the ctenophore, Mnemiopsis leidyi. PloS One 6(9):e24152. https://doi.org/10.1371/journal.pone.0024152

37. Camus A, Perea-Gomez A, Moreau A, Collignon J (2006) Absence of Nodal signaling promotes precocious neural differentiation in the mouse embryo. Dev Biol 295(2):743-755. https:// doi.org/10.1016/j.ydbio.2006.03.047

38. Mesnard D, Guzman-Ayala M, Constam DB (2006) Nodal specifies embryonic visceral endoderm and sustains pluripotent cells in the epiblast before overt axial patterning. Development 133(13):2497-2505. https://doi.org/10.1242/dev.02413

39. Tam PP, Loebel DA (2007) Gene function in mouse embryogenesis: get set for gastrulation. Nat Rev Genet 8(5):368-381. https://doi.org/10.1038/nrg2084

40. Singh AM, Reynolds D, Cliff T, Ohtsuka S, Mattheyses AL, Sun Y, Menendez L, Kulik M, Dalton S (2012) Signaling network crosstalk in human pluripotent cells: a Smad2/3-regulated switch that controls the balance between self-renewal and differentiation. Cell Stem Cell 10(3):312-326. https://doi.org/10.1016/j. stem.2012.01.014

41. Burdsal CA, Flannery ML, Pedersen RA (1998) FGF-2 alters the fate of mouse epiblast from ectoderm to mesoderm in vitro. Dev Biol 198(2):231-244

42. Carmeliet P (2000) Developmental biology. One cell, two fates. Nature 408(6808):43, 45. https://doi.org/10.1038/35040684

43. Palis J, McGrath KE, Kingsley PD (1995) Initiation of hematopoiesis and vasculogenesis in murine yolk sac explants. Blood 86(1):156-163

44. Yoder MC (2015) Differentiation of pluripotent stem cells into endothelial cells. Curr Opin Hematol 22(3):252-257. https://doi. org/10.1097/MOH.0000000000000140

45. Ding BS, Cao Z, Lis R, Nolan DJ, Guo P, Simons M, Penfold ME, Shido K, Rabbany SY, Rafii S (2014) Divergent angiocrine signals from vascular niche balance liver regeneration and fibrosis. Nature 505(7481):97-102. https://doi.org/10.1038/ nature 12681

46. Tan KS, Tamura K, Lai MI, Veerakumarasivam A, Nakanishi Y, Ogawa M, Sugiyama D (2013) Molecular pathways governing development of vascular endothelial cells from ES/iPS cells. Stem Cell Rev 9(5):586-598. https://doi.org/10.1007/ s12015-013-9450-7

47. Adams WJ, Zhang Y, Cloutier J, Kuchimanchi P, Newton G, Sehrawat S, Aird WC, Mayadas TN, Luscinskas FW, Garcia-Cardena G (2013) Functional vascular endothelium derived from human induced pluripotent stem cells. Stem Cell Rep 1(2):105-113. https://doi.org/10.1016/j.stemcr.2013.06.007

48. Wilson HK, Canfield SG, Shusta EV, Palecek SP (2014) Concise review: tissue-specific microvascular endothelial cells derived from human pluripotent stem cells. Stem Cells 32(12):30373045. https://doi.org/10.1002/stem.1797

49. Di Bernardini E, Campagnolo P, Margariti A, Zampetaki A, Karamariti E, Hu Y, Xu Q (2014) Endothelial lineage differentiation from induced pluripotent stem cells is regulated by microRNA-21 and transforming growth factor beta2 (TGF-beta2) pathways. 
J Biol Chem 289(6):3383-3393. https://doi.org/10.1074/jbc. M113.495531

50. Patsch C, Challet-Meylan L, Thoma EC, Urich E, Heckel T, O'Sullivan JF, Grainger SJ, Kapp FG, Sun L, Christensen K, Xia Y, Florido MH, He W, Pan W, Prummer M, Warren CR, Jakob-Roetne R, Certa U, Jagasia R, Freskgard PO, Adatto I, Kling D, Huang P, Zon LI, Chaikof EL, Gerszten RE, Graf M, Iacone R, Cowan CA (2015) Generation of vascular endothelial and smooth muscle cells from human pluripotent stem cells. Nat Cell Biol 17(8):994-1003. https://doi.org/10.1038/ncb3205

51. Wang L, Xiang M, Liu Y, Sun N, Lu M, Shi Y, Wang X, Meng D, Chen S, Qin J (2016) Human induced pluripotent stem cells derived endothelial cells mimicking vascular inflammatory response under flow. Biomicrofluidics 10(1):014106. https://doi. org/10.1063/1.4940041

52. Orlova VV, van den Hil FE, Petrus-Reurer S, Drabsch Y, Ten Dijke P, Mummery CL (2014) Generation, expansion and functional analysis of endothelial cells and pericytes derived from human pluripotent stem cells. Nat Protoc 9(6):1514-1531. https://doi.org/10.1038/nprot.2014.102

53. Taura D, Sone M, Homma K, Oyamada N, Takahashi K, Tamura N, Yamanaka S, Nakao K (2009) Induction and isolation of vascular cells from human induced pluripotent stem cells-brief report. Arterioscler Thromb Vasc Biol 29(7):1100-1103. https:// doi.org/10.1161/ATVBAHA.108.182162

54. Choi KD, Yu J, Smuga-Otto K, Salvagiotto G, Rehrauer W, Vodyanik M, Thomson J, Slukvin I (2009) Hematopoietic and endothelial differentiation of human induced pluripotent stem cells. Stem Cells 27(3):559-567. https://doi.org/10.1634/ stemcells.2008-0922

55. Kane NM, Xiao Q, Baker AH, Luo Z, Xu Q, Emanueli C (2011) Pluripotent stem cell differentiation into vascular cells: a novel technology with promises for vascular re(generation). Pharmacol Ther 129(1):29-49. https://doi.org/10.1016/j. pharmthera.2010.10.004

56. Nourse MB, Halpin DE, Scatena M, Mortisen DJ, Tulloch NL, Hauch KD, Torok-Storb B, Ratner BD, Pabon L, Murry CE (2010) VEGF induces differentiation of functional endothelium from human embryonic stem cells: implications for tissue engineering. Arterioscler Thromb Vasc Biol 30(1):80-89. https://doi. org/10.1161/ATVBAHA.109.194233

57. Ng ES, Davis R, Stanley EG, Elefanty AG (2008) A protocol describing the use of a recombinant protein-based, animal product-free medium (APEL) for human embryonic stem cell differentiation as spin embryoid bodies. Nat Protoc 3(5):768-776. https://doi.org/10.1038/nprot.2008.42

58. James D, Nam HS, Seandel M, Nolan D, Janovitz T, Tomishima M, Studer L, Lee G, Lyden D, Benezra R, Zaninovic N, Rosenwaks Z, Rabbany SY, Rafii S (2010) Expansion and maintenance of human embryonic stem cell-derived endothelial cells by TGFbeta inhibition is Id 1 dependent. Nat Biotechnol 28(2):161-166. https://doi.org/10.1038/nbt.1605

59. White MP, Rufaihah AJ, Liu L, Ghebremariam YT, Ivey KN, Cooke JP, Srivastava D (2013) Limited gene expression variation in human embryonic stem cell and induced pluripotent stem cell-derived endothelial cells. Stem Cells 31(1):92-103. https:// doi.org/10.1002/stem.1267

60. Park TS, Bhutto I, Zimmerlin L, Huo JS, Nagaria P, Miller D, Rufaihah AJ, Talbot C, Aguilar J, Grebe R, Merges C, ReijoPera R, Feldman RA, Rassool F, Cooke J, Lutty G, Zambidis ET (2014) Vascular progenitors from cord blood-derived induced pluripotent stem cells possess augmented capacity for regenerating ischemic retinal vasculature. Circulation 129(3):359-372. https://doi.org/10.1161/CIRCULATIONAHA.113.003000

61. Lippmann ES, Azarin SM, Kay JE, Nessler RA, Wilson HK, Al-Ahmad A, Palecek SP, Shusta EV (2012) Derivation of blood-brain barrier endothelial cells from human pluripotent stem cells. Nat Biotechnol 30(8):783-791. https://doi. org/10.1038/nbt.2247

62. Chen G, Gulbranson DR, Hou Z, Bolin JM, Ruotti V, Probasco MD, Smuga-Otto K, Howden SE, Diol NR, Propson NE, Wagner R, Lee GO, Antosiewicz-Bourget J, Teng JM, Thomson JA (2011) Chemically defined conditions for human iPSC derivation and culture. Nat Methods 8(5):424-429. https://doi.org/10.1038/ nmeth. 1593

63. Beers J, Gulbranson DR, George N, Siniscalchi LI, Jones J, Thomson JA, Chen G (2012) Passaging and colony expansion of human pluripotent stem cells by enzyme-free dissociation in chemically defined culture conditions. Nat Protoc 7(11):20292040. https://doi.org/10.1038/nprot.2012.130

64. Katt ME, Xu ZS, Gerecht S, Searson PC (2016) Human brain microvascular endothelial cells derived from the BC1 iPS cell line exhibit a blood-brain barrier phenotype. PLoS One 11(4):e0152105. https://doi.org/10.1371/journal.pone.0152105

65. Lippmann ES, Al-Ahmad A, Azarin SM, Palecek SP, Shusta EV (2014) A retinoic acid-enhanced, multicellular human blood-brain barrier model derived from stem cell sources. Sci Rep 4:4160. https://doi.org/10.1038/srep04160

66. Orlova VV, Drabsch Y, Freund C, Petrus-Reurer S, van den Hil FE, Muenthaisong S, Dijke PT, Mummery CL (2014) Functionality of endothelial cells and pericytes from human pluripotent stem cells demonstrated in cultured vascular plexus and zebrafish xenografts. Arterioscler Thromb Vasc Biol 34(1):177-186. https://doi.org/10.1161/ ATVBAHA.113.302598

67. Ikuno T, Masumoto H, Yamamizu K, Yoshioka M, Minakata K, Ikeda T, Sakata R, Yamashita JK (2017) Efficient and robust differentiation of endothelial cells from human induced pluripotent stem cells via lineage control with VEGF and cyclic AMP. PLoS One 12(3):e0173271. https://doi.org/10.1371/journal. pone. 0173271

68. Harding A, Cortez-Toledo E, Magner NL, Beegle JR, ColealBergum DP, Hao D, Wang A, Nolta JA, Zhou P (2017) Highly efficient differentiation of endothelial cells from pluripotent stem cells requires the MAPK and the PI3K pathways. Stem Cells 35(4):909-919. https://doi.org/10.1002/stem.2577

69. Ginsberg M, James D, Ding BS, Nolan D, Geng F, Butler JM, Schachterle W, Pulijaal VR, Mathew S, Chasen ST, Xiang J, Rosenwaks Z, Shido K, Elemento O, Rabbany SY, Rafii S (2012) Efficient direct reprogramming of mature amniotic cells into endothelial cells by ETS factors and TGFbeta suppression. Cell 151(3):559-575. https://doi.org/10.1016/j.cell.2012.09.032

70. Dejana E, Taddei A, Randi AM (2007) Foxs and Ets in the transcriptional regulation of endothelial cell differentiation and angiogenesis. Biochem Biophys Acta 1775(2):298-312. https:// doi.org/10.1016/j.bbcan.2007.05.003

71. Morita R, Suzuki M, Kasahara H, Shimizu N, Shichita T, Sekiya T, Kimura A, Sasaki K, Yasukawa H, Yoshimura A (2015) ETS transcription factor ETV2 directly converts human fibroblasts into functional endothelial cells. Proc Natl Acad Sci USA 112(1):160-165. https://doi.org/10.1073/pnas.1413234112

72. Kurian L, Sancho-Martinez I, Nivet E, Aguirre A, Moon K, Pendaries C, Volle-Challier C, Bono F, Herbert JM, Pulecio J, Xia Y, Li M, Montserrat N, Ruiz S, Dubova I, Rodriguez C, Denli AM, Boscolo FS, Thiagarajan RD, Gage FH, Loring JF, Laurent LC, Izpisua Belmonte JC (2013) Conversion of human fibroblasts to angioblast-like progenitor cells. Nat Methods 10(1):77-83. https://doi.org/10.1038/nmeth.2255

73. Han JK, Chang SH, Cho HJ, Choi SB, Ahn HS, Lee J, Jeong H, Youn SW, Lee HJ, Kwon YW, Cho HJ, Oh BH, Oettgen P, Park YB, Kim HS (2014) Direct conversion of adult skin fibroblasts to endothelial cells by defined 
factors. Circulation 130(14):1168-1178. https://doi.org/10.1161/ CIRCULATIONAHA.113.007727

74. Cahan P, Li H, Morris SA, Lummertz da Rocha E, Daley GQ, Collins JJ (2014) CellNet: network biology applied to stem cell engineering. Cell 158(4):903-915. https://doi.org/10.1016/j. cell.2014.07.020

75. Liu F, Kang I, Park C, Chang LW, Wang W, Lee D, Lim DS, Vittet D, Nerbonne JM, Choi K (2012) ER71 specifies Flk-1 ${ }^{+}$ hemangiogenic mesoderm by inhibiting cardiac mesoderm and Wnt signaling. Blood 119(14):3295-3305. https://doi. org/10.1182/blood-2012-01-403766

76. Shi X, Richard J, Zirbes KM, Gong W, Lin G, Kyba M, Thomson JA, Koyano-Nakagawa N, Garry DJ (2014) Cooperative interaction of Etv2 and Gata2 regulates the development of endothelial and hematopoietic lineages. Dev Biol 389(2):208-218. https:// doi.org/10.1016/j.ydbio.2014.02.018

77. Chen T, Margariti A, Kelaini S, Cochrane A, Guha ST, Hu Y, Stitt AW, Zhang L, Xu Q (2015) MicroRNA-199b modulates vascular cell fate during iPS cell differentiation by targeting the notch ligand jagged 1 AND enhancing VEGF signaling. Stem Cells 33(5):1405-1418. https://doi.org/10.1002/stem.1930

78. Rufaihah AJ, Huang NF, Kim J, Herold J, Volz KS, Park TS, Lee JC, Zambidis ET, Reijo-Pera R, Cooke JP (2013) Human induced pluripotent stem cell-derived endothelial cells exhibit functional heterogeneity. Am J Transl Res 5(1):21-35

79. Sriram G, Tan JY, Islam I, Rufaihah AJ, Cao T (2015) Efficient differentiation of human embryonic stem cells to arterial and venous endothelial cells under feeder- and serum-free conditions. Stem Cell Res Ther 6:261. https://doi.org/10.1186/ s13287-015-0260-5

80. Majesky MW (2007) Developmental basis of vascular smooth muscle diversity. Arterioscler Thromb Vasc Biol 27(6):12481258. https://doi.org/10.1161/ATVBAHA.107.141069

81. Granata A, Bernard WG, Zhao N, McCafferty J, Lilly B, Sinha S (2015) Temporal and embryonic lineage-dependent regulation of human vascular SMC development by NOTCH3. Stem Cells Dev 24(7):846-856. https://doi.org/10.1089/scd.2014.0520

82. Sinha S, Iyer D, Granata A (2014) Embryonic origins of human vascular smooth muscle cells: implications for in vitro modeling and clinical application. Cell Mol Life Sci 71(12):2271-2288. https://doi.org/10.1007/s00018-013-1554-3

83. Cordes KR, Sheehy NT, White MP, Berry EC, Morton SU, Muth AN, Lee TH, Miano JM, Ivey KN, Srivastava D (2009) miR145 and miR-143 regulate smooth muscle cell fate and plasticity. Nature 460(7256):705-710. https://doi.org/10.1038/nature08195

84. Jiang X, Rowitch DH, Soriano P, McMahon AP, Sucov HM (2000) Fate of the mammalian cardiac neural crest. Development 127(8):1607-1616

85. Wasteson P, Johansson BR, Jukkola T, Breuer S, Akyurek LM, Partanen J, Lindahl P (2008) Developmental origin of smooth muscle cells in the descending aorta in mice. Development 135(10):1823-1832. https://doi.org/10.1242/dev.020958

86. Yang L, Geng Z, Nickel T, Johnson C, Gao L, Dutton J, Hou C, Zhang J (2016) Differentiation of human induced-pluripotent stem cells into smooth-muscle cells: two novel protocols. PLoS One 11(1):e0147155. https://doi.org/10.1371/journal. pone. 0147155

87. Sundaram S, One J, Siewert J, Teodosescu S, Zhao L, Dimitrievska S, Qian H, Huang AH, Niklason L (2014) Tissue-engineered vascular grafts created from human induced pluripotent stem cells. Stem Cells Transl Med 3(12):1535-1543. https://doi. org/10.5966/sctm.2014-0065

88. Lee TH, Song SH, Kim KL, Yi JY, Shin GH, Kim JY, Kim J, Han YM, Lee SH, Lee SH, Shim SH, Suh W (2010) Functional recapitulation of smooth muscle cells via induced pluripotent stem cells from human aortic smooth muscle cells. Circ Res 106(1):120-128. https://doi.org/10.1161/ CIRCRESAHA.109.207902

89. Ge X, Ren Y, Bartulos O, Lee MY, Yue Z, Kim KY, Li W, Amos PJ, Bozkulak EC, Iyer A, Zheng W, Zhao H, Martin KA, Kotton DN, Tellides G, Park IH, Yue L, Qyang Y (2012) Modeling supravalvular aortic stenosis syndrome with human induced pluripotent stem cells. Circulation 126(14):1695-1704. https:// doi.org/10.1161/CIRCULATIONAHA.112.116996

90. Xie CQ, Zhang J, Villacorta L, Cui T, Huang H, Chen YE (2007) A highly efficient method to differentiate smooth muscle cells from human embryonic stem cells. Arterioscler Thromb Vasc Biol 27(12):e311-e312. https://doi.org/10.1161/ ATVBAHA.107.154260

91. Lin B, Kim J, Li Y, Pan H, Carvajal-Vergara X, Salama G, Cheng T, Li Y, Lo CW, Yang L (2012) High-purity enrichment of functional cardiovascular cells from human iPS cells. Cardiovasc Res 95(3):327-335. https://doi.org/10.1093/cvr/cvs185

92. Rensen SS, Doevendans PA, van Eys GJ (2007) Regulation and characteristics of vascular smooth muscle cell phenotypic diversity. Neth Heart J Mon J Neth Soc Cardiol Neth Heart Found 15(3):100-108

93. Ratz PH (2015) Mechanics of vascular smooth muscle. Compr Physiol 6(1):111-168. https://doi.org/10.1002/cphy.c140072

94. Wanjare M, Kuo F, Gerecht S (2013) Derivation and maturation of synthetic and contractile vascular smooth muscle cells from human pluripotent stem cells. Cardiovasc Res 97(2):321-330. https://doi.org/10.1093/cvr/cvs315

95. Cheung C, Bernardo AS, Pedersen RA, Sinha S (2014) Directed differentiation of embryonic origin-specific vascular smooth muscle subtypes from human pluripotent stem cells. Nat Protoc 9(4):929-938. https://doi.org/10.1038/nprot.2014.059

96. Jiao J, Xiong W, Wang L, Yang J, Qiu P, Hirai H, Shao L, Milewicz D, Chen YE, Yang B (2016) Differentiation defect in neural crest-derived smooth muscle cells in patients with aortopathy associated with bicuspid aortic valves. EBioMedicine 10:282290. https://doi.org/10.1016/j.ebiom.2016.06.045

97. Granata A, Serrano F, Bernard WG, McNamara M, Low L, Sastry P, Sinha S (2017) An iPSC-derived vascular model of Marfan syndrome identifies key mediators of smooth muscle cell death. Nat Genet 49(1):97-109. https://doi.org/10.1038/ng.3723

98. Skarmoutsou E, Trovato C, Granata M, Rossi GA, Mosca A, Longo V, Gangemi P, Pettinato M, D’Amico F, Mazzarino MC (2015) Biological therapy induces expression changes in Notch pathway in psoriasis. Arch Dermatol Res 307(10):863-873. https://doi.org/10.1007/s00403-015-1594-7

99. Collado MS, Cole BK, Figler RA, Lawson M, Manka D, Simmers MB, Hoang S, Serrano F, Blackman BR, Sinha S, Wamhoff BR (2017) Exposure of induced pluripotent stem cell-derived vascular endothelial and smooth muscle cells in coculture to hemodynamics induces primary vascular cell-like phenotypes. Stem Cells Transl Med. https://doi.org/10.1002/sctm.17-0004

100. Cheung C, Bernardo AS, Trotter MW, Pedersen RA, Sinha S (2012) Generation of human vascular smooth muscle subtypes provides insight into embryological origin-dependent disease susceptibility. Nat Biotechnol 30(2):165-173. https://doi. org/10.1038/nbt.2107

101. Tresoldi C, Pellegata AF, Mantero S (2015) Cells and stimuli in small-caliber blood vessel tissue engineering. Regen Med 10(4):505-527. https://doi.org/10.2217/rme.15.19

102. Zhang WJ, Liu W, Cui L, Cao Y (2007) Tissue engineering of blood vessel. J Cell Mol Med 11(5):945-957. https://doi. org/10.1111/j.1582-4934.2007.00099.x

103. Grenier G, Remy-Zolghadri M, Guignard R, Bergeron F, Labbe R, Auger FA, Germain L (2003) Isolation and culture of the three vascular cell types from a small vein biopsy sample. In Vitro 
Cell Dev Biol Anim 39(3-4):131-139. https://doi.org/10.1007/ s11626-003-0007-y

104. McKee JA, Banik SS, Boyer MJ, Hamad NM, Lawson JH, Niklason LE, Counter CM (2003) Human arteries engineered in vitro. EMBO Rep 4(6):633-638. https://doi.org/10.1038/sj.embor. embor847

105. Shao R, Guo X (2004) Human microvascular endothelial cells immortalized with human telomerase catalytic protein: a model for the study of in vitro angiogenesis. Biochem Biophys Res Commun 321(4):788-794. https://doi.org/10.1016/j. bbrc.2004.07.033

106. Li Z, Hu S, Ghosh Z, Han Z, Wu JC (2011) Functional characterization and expression profiling of human induced pluripotent stem cell- and embryonic stem cell-derived endothelial cells. Stem Cells Dev 20(10):1701-1710. https://doi.org/10.1089/ scd.2010.0426

107. Wang L, Su W, Du W, Xu Y, Wang L, Kong D, Han Z, Zheng $\mathrm{G}, \mathrm{Li} \mathrm{Z}$ (2015) Gene and microRNA profiling of human induced pluripotent stem cell-derived endothelial cells. Stem Cell Rev 11(2):219-227. https://doi.org/10.1007/s12015-014-9582-4

108. Kokudo T, Suzuki Y, Yoshimatsu Y, Yamazaki T, Watabe T, Miyazono K (2008) Snail is required for TGFbeta-induced endothelial-mesenchymal transition of embryonic stem cellderived endothelial cells. J Cell Sci 121(Pt 20):3317-3324. https://doi.org/10.1242/jcs.028282

109. Feng Q, Lu SJ, Klimanskaya I, Gomes I, Kim D, Chung Y, Honig GR, Kim KS, Lanza R (2010) Hemangioblastic derivatives from human induced pluripotent stem cells exhibit limited expansion and early senescence. Stem Cells 28(4):704-712. https://doi.org/10.1002/stem.321

110. Stadtfeld M, Apostolou E, Akutsu H, Fukuda A, Follett P, Natesan S, Kono T, Shioda T, Hochedlinger K (2010) Aberrant silencing of imprinted genes on chromosome $12 \mathrm{qF} 1$ in mouse induced pluripotent stem cells. Nature 465(7295):175-181. https://doi.org/10.1038/nature09017

111. Ghosh Z, Wilson KD, Wu Y, Hu S, Quertermous T, Wu JC (2010) Persistent donor cell gene expression among human induced pluripotent stem cells contributes to differences with human embryonic stem cells. PLoS One 5(2):e8975. https:// doi.org/10.1371/journal.pone.0008975

112. Urbach A, Bar-Nur O, Daley GQ, Benvenisty N (2010) Differential modeling of fragile $\mathrm{X}$ syndrome by human embryonic stem cells and induced pluripotent stem cells. Cell Stem Cell 6(5):407-411. https://doi.org/10.1016/j.stem.2010.04.005

113. Hu S, Zhao MT, Jahanbani F, Shao NY, Lee WH, Chen H, Snyder MP, Wu JC (2016) Effects of cellular origin on differentiation of human induced pluripotent stem cell-derived endothelial cells. JCI Insight. https://doi.org/10.1172/jci.insight.85558

114. Misra A, Sheikh AQ, Kumar A, Luo J, Zhang J, Hinton RB, Smoot L, Kaplan P, Urban Z, Qyang Y, Tellides G, Greif DM (2016) Integrin beta3 inhibition is a therapeutic strategy for supravalvular aortic stenosis. J Exp Med 213(3):451-463. https://doi.org/10.1084/jem.20150688

115. Bargehr J, Low L, Cheung C, Bernard WG, Iyer D, Bennett MR, Gambardella L, Sinha S (2016) Embryological origin of human smooth muscle cells influences their ability to support endothelial network formation. Stem Cells Transl Med 5(7):946-959. https://doi.org/10.5966/sctm.2015-0282

116. Wang G, Jacquet L, Karamariti E, Xu Q (2015) Origin and differentiation of vascular smooth muscle cells. J Physiol 593(14):3013-3030. https://doi.org/10.1113/JP270033

117. Belair DG, Whisler JA, Valdez J, Velazquez J, Molenda JA, Vickerman V, Lewis R, Daigh C, Hansen TD, Mann DA, Thomson JA, Griffith LG, Kamm RD, Schwartz MP, Murphy WL (2015) Human vascular tissue models formed from human induced pluripotent stem cell derived endothelial cells. Stem cell Rev 11(3):511-525. https://doi.org/10.1007/ s12015-014-9549-5

118. Zanotelli MR, Ardalani H, Zhang J, Hou Z, Nguyen EH, Swanson S, Nguyen BK, Bolin J, Elwell A, Bischel LL, Xie AW, Stewart R, Beebe DJ, Thomson JA, Schwartz MP, Murphy WL (2016) Stable engineered vascular networks from human induced pluripotent stem cell-derived endothelial cells cultured in synthetic hydrogels. Acta Biomater 35:32-41. https://doi.org/10.1016/j. actbio.2016.03.001

119. Kurokawa YK, Yin RT, Shang MR, Shirure VS, Moya ML, George SC (2017) Human iPS-derived endothelial cells for 3D microphysiological systems. Tissue Eng Part C Methods. https:// doi.org/10.1089/ten.TEC.2017.0133

120. Gu M, Shao NY, Sa S, Li D, Termglinchan V, Ameen M, Karakikes I, Sosa G, Grubert F, Lee J, Cao A, Taylor S, Ma Y, Zhao Z, Chappell J, Hamid R, Austin ED, Gold JD, Wu JC, Snyder MP, Rabinovitch M (2017) Patient-specific iPSC-derived endothelial cells uncover pathways that protect against pulmonary hypertension in BMPR2 mutation carriers. Cell Stem Cell 20(4):490-504 e495. https://doi.org/10.1016/j.stem.2016.08.019

121. Tseng WL, Chou SJ, Chiang HC, Wang ML, Chien CS, Chen KH, Leu HB, Wang CY, Chang YL, Liu YY, Jong YJ, Lin SZ, Chiou SH, Lin SJ, Yu WC (2017) Imbalanced production of reactive oxygen species and mitochondrial antioxidant SOD2 in Fabry disease-specific human induced pluripotent stem cell-differentiated vascular endothelial cells. Cell Transplant 26(3):513527. https://doi.org/10.3727/096368916X694265

122. Zhang J, Lian Q, Zhu G, Zhou F, Sui L, Tan C, Mutalif RA, Navasankari R, Zhang Y, Tse HF, Stewart CL, Colman A (2011) A human iPSC model of Hutchinson Gilford Progeria reveals vascular smooth muscle and mesenchymal stem cell defects. Cell Stem Cell 8(1):31-45. https://doi.org/10.1016/j. stem.2010.12.002

123. Biel NM, Santostefano KE, DiVita BB, El Rouby N, Carrasquilla SD, Simmons C, Nakanishi M, Cooper-DeHoff RM, Johnson JA, Terada N (2015) Vascular smooth muscle cells from hypertensive patient-derived induced pluripotent stem cells to advance hypertension pharmacogenomics. Stem Cells Transl Med 4(12):13801390. https://doi.org/10.5966/sctm.2015-0126

124. Vazao H, Rosa S, Barata T, Costa R, Pitrez PR, Honorio I, de Vries MR, Papatsenko D, Benedito R, Saris D, Khademhosseini A, Quax PH, Pereira CF, Mercader N, Fernandes H, Ferreira L (2017) High-throughput identification of small molecules that affect human embryonic vascular development. Proc Natl Acad Sci USA. https://doi.org/10.1073/pnas.1617451114

125. Walden R, Tomlinson B (2011) Cardiovascular disease. In: Benzie IFF, Wachtel-Galor S (eds) Herbal medicine: biomolecular and clinical aspects, 2nd edn. CRC Press/Taylor \& Francis, Boca Raton

126. Heidenreich PA, Trogdon JG, Khavjou OA, Butler J, Dracup K, Ezekowitz MD, Finkelstein EA, Hong Y, Johnston SC, Khera A, Lloyd-Jones DM, Nelson SA, Nichol G, Orenstein D, Wilson PW, Woo YJ, American Heart Association Advocacy Coordinating $\mathrm{C}$, Stroke $\mathrm{C}$, Council on Cardiovascular R, Intervention, Council on Clinical C, Council on E, Prevention, Council on A, Thrombosis, Vascular B, Council on C, Critical C, Perioperative, Resuscitation, Council on Cardiovascular N, Council on the Kidney in Cardiovascular D, Council on Cardiovascular S, Anesthesia, Interdisciplinary Council on Quality of C, Outcomes R (2011) Forecasting the future of cardiovascular disease in the United States: a policy statement from the American Heart Association. Circulation 123(8):933-944. https://doi.org/10.1161/ CIR.0b013e31820a55f5

127. Writing Group M, Mozaffarian D, Benjamin EJ, Go AS, Arnett DK, Blaha MJ, Cushman M, Das SR, de Ferranti S, Despres JP, Fullerton HJ, Howard VJ, Huffman MD, Isasi CR, Jimenez MC, 
Judd SE, Kissela BM, Lichtman JH, Lisabeth LD, Liu S, Mackey RH, Magid DJ, McGuire DK, Mohler ER 3rd, Moy CS, Muntner P, Mussolino ME, Nasir K, Neumar RW, Nichol G, Palaniappan L, Pandey DK, Reeves MJ, Rodriguez CJ, Rosamond W, Sorlie PD, Stein J, Towfighi A, Turan TN, Virani SS, Woo D, Yeh RW, Turner MB, American Heart Association Statistics C, Stroke Statistics S (2016) Heart disease and stroke statistics-2016 update: a report from the American Heart Association. Circulation 133(4):e38-e360. https://doi.org/10.1161/cir.0000000000000350

128. Nakayama KH, Joshi PA, Lai ES, Gujar P, Joubert LM, Chen B, Huang NF (2015) Bilayered vascular graft derived from human induced pluripotent stem cells with biomimetic structure and function. Regen Med 10(6):745-755. https://doi.org/10.2217/ rme. 15.45

129. Lloyd-Jones D, Adams RJ, Brown TM, Carnethon M, Dai S, De Simone G, Ferguson TB, Ford E, Furie K, Gillespie C, Go A, Greenlund K, Haase N, Hailpern S, Ho PM, Howard V, Kissela B, Kittner S, Lackland D, Lisabeth L, Marelli A, McDermott MM, Meigs J, Mozaffarian D, Mussolino M, Nichol G, Roger VL, Rosamond W, Sacco R, Sorlie P, Thom T, WasserthielSmoller S, Wong ND, Wylie-Rosett J (2010) Heart disease and stroke statistics-2010 update: a report from the American Heart Association. Circulation 121(7):e46-e215. https://doi. org/10.1161/CIRCULATIONAHA.109.192667

130. Wilson WR, Bower TC, Creager MA, Amin-Hanjani S, O'Gara PT, Lockhart PB, Darouiche RO, Ramlawi B, Derdeyn CP, Bolger AF, Levison ME, Taubert KA, Baltimore RS, Baddour LM (2016) Vascular graft infections, mycotic aneurysms, and endovascular infections: a scientific statement from the American Heart Association. Circulation 134(20):e412-e460. https://doi. org/10.1161/CIR.0000000000000457

131. Hasse B, Husmann L, Zinkernagel A, Weber R, Lachat M, Mayer D (2013) Vascular graft infections. Swiss Med Wly 143:w13754. https://doi.org/10.4414/smw.2013.13754

132. Rogers C, Welt FG, Karnovsky MJ, Edelman ER (1996) Monocyte recruitment and neointimal hyperplasia in rabbits. Coupled inhibitory effects of heparin. Arterioscler Thromb Vasc Biol 16(10):1312-1318

133. Shagdarsuren E, Djalali-Talab Y, Aurrand-Lions M, Bidzhekov K, Liehn EA, Imhof BA, Weber C, Zernecke A (2009) Importance of junctional adhesion molecule-C for neointimal hyperplasia and monocyte recruitment in atherosclerosis-prone micebrief report. Arterioscler Thromb Vasc Biol 29(8):1161-1163. https://doi.org/10.1161/ATVBAHA.109.187898

134. Neff LP, Tillman BW, Yazdani SK, Machingal MA, Yoo JJ, Soker S, Bernish BW, Geary RL, Christ GJ (2011) Vascular smooth muscle enhances functionality of tissue-engineered blood vessels in vivo. J Vasc Surg 53(2):426-434. https://doi.org/10.1016/j. jvs.2010.07.054

135. Heydarkhan-Hagvall S, Helenius G, Johansson BR, Li JY, Mattsson E, Risberg B (2003) Co-culture of endothelial cells and smooth muscle cells affects gene expression of angiogenic factors. J Cell Biochem 89(6):1250-1259. https://doi.org/10.1002/ jcb. 10583

136. Michel JB, Li Z, Lacolley P (2012) Smooth muscle cells and vascular diseases. Cardiovasc Res 95(2):135-137. https://doi. org/10.1093/cvr/cvs172

137. Veith FJ, Gupta SK, Ascer E, White-Flores S, Samson RH, Scher LA, Towne JB, Bernhard VM, Bonier P, Flinn WR et al (1986) Six-year prospective multicenter randomized comparison of autologous saphenous vein and expanded polytetrafluoroethylene grafts in infrainguinal arterial reconstructions. J Vasc Surg 3(1):104-114

138. Genovese EA, Avgerinos ED, Baril DT, Makaroun MS, Chaer RA (2016) Bio-absorbable antibiotic impregnated beads for the treatment of prosthetic vascular graft infections. Vascular 24(6):590-597. https://doi.org/10.1177/1708538116630859

139. Huang AH, Niklason LE (2014) Engineering of arteries in vitro. Cell Mol Life Sci 71(11):2103-2118. https://doi.org/10.1007/ s00018-013-1546-3

140. Ren X, Moser PT, Gilpin SE, Okamoto T, Wu T, Tapias LF, Mercier FE, Xiong L, Ghawi R, Scadden DT, Mathisen DJ, Ott HC (2015) Engineering pulmonary vasculature in decellularized rat and human lungs. Nat Biotechnol 33(10):1097-1102. https:// doi.org/10.1038/nbt.3354

141. Samuel R, Daheron L, Liao S, Vardam T, Kamoun WS, Batista A, Buecker C, Schafer R, Han X, Au P, Scadden DT, Duda DG, Fukumura D, Jain RK (2013) Generation of functionally competent and durable engineered blood vessels from human induced pluripotent stem cells. Proc Natl Acad Sci USA 110(31):1277412779. https://doi.org/10.1073/pnas. 1310675110

142. Koike N, Fukumura D, Gralla O, Au P, Schechner JS, Jain RK (2004) Tissue engineering: creation of long-lasting blood vessels. Nature 428(6979):138-139. https://doi.org/10.1038/428138a

143. Sena CM, Pereira AM, Seica R (2013) Endothelial dysfunction-a major mediator of diabetic vascular disease. Biochem Biophys Acta 1832(12):2216-2231. https://doi.org/10.1016/j. bbadis.2013.08.006

144. Bento CF, Pereira P (2011) Regulation of hypoxia-inducible factor 1 and the loss of the cellular response to hypoxia in diabetes. Diabetologia 54(8):1946-1956. https://doi.org/10.1007/ s00125-011-2191-8

145. Highlander P, Shaw GP (2010) Current pharmacotherapeutic concepts for the treatment of cardiovascular disease in diabetics. Ther Adv Cardiovasc Dis 4(1):43-54. https://doi. org/10.1177/1753944709354305

146. Nesto RW (2004) Correlation between cardiovascular disease and diabetes mellitus: current concepts. Am J Med 116(Suppl 5A):11S-22S. https://doi.org/10.1016/j.amjmed.2003.10.016

147. Chan XY, Black R, Dickerman K, Federico J, Levesque M, Mumm J, Gerecht S (2015) Three-dimensional vascular network assembly from diabetic patient-derived induced pluripotent stem cells. Arterioscler Thromb Vasc Biol 35(12):2677-2685. https:// doi.org/10.1161/ATVBAHA.115.306362

148. Sen S, McDonald SP, Coates PT, Bonder CS (2011) Endothelial progenitor cells: novel biomarker and promising cell therapy for cardiovascular disease. Clin Sci 120(7):263-283. https://doi. org/10.1042/CS20100429

149. Berezin AE (2017) Endothelial progenitor cells dysfunction and impaired tissue reparation: the missed link in diabetes mellitus development. Diabetes Metab Syndr 11(3):215-220. https://doi. org/10.1016/j.dsx.2016.08.007

150. Menegazzo L, Albiero M, Avogaro A, Fadini GP (2012) Endothelial progenitor cells in diabetes mellitus. BioFactors 38(3):194-202. https://doi.org/10.1002/biof.1016

151. Kusuma S, Shen YI, Hanjaya-Putra D, Mali P, Cheng L, Gerecht S (2013) Self-organized vascular networks from human pluripotent stem cells in a synthetic matrix. Proc Natl Acad Sci USA 110(31):12601-12606. https://doi.org/10.1073/pnas.1306562110

152. Loomans CJ, de Koning EJ, Staal FJ, Rookmaaker MB, Verseyden C, de Boer HC, Verhaar MC, Braam B, Rabelink TJ, van Zonneveld AJ (2004) Endothelial progenitor cell dysfunction: a novel concept in the pathogenesis of vascular complications of type 1 diabetes. Diabetes 53(1):195-199

153. Hu J, Wang Y, Jiao J, Liu Z, Zhao C, Zhou Z, Zhang Z, Forde K, Wang L, Wang J, Baylink DJ, Zhang XB, Gao S, Yang B, Chen YE, Ma PX (2015) Patient-specific cardiovascular progenitor cells derived from integration-free induced pluripotent stem cells for vascular tissue regeneration. Biomaterials 73:51-59. https:// doi.org/10.1016/j.biomaterials.2015.09.008 
154. Ott HC, Clippinger B, Conrad C, Schuetz C, Pomerantseva I, Ikonomou L, Kotton D, Vacanti JP (2010) Regeneration and orthotopic transplantation of a bioartificial lung. Nat Med 16(8):927-933. https://doi.org/10.1038/nm.2193

155. Petersen TH, Calle EA, Zhao L, Lee EJ, Gui L, Raredon MB, Gavrilov K, Yi T, Zhuang ZW, Breuer C, Herzog E, Niklason LE (2010) Tissue-engineered lungs for in vivo implantation. Science 329(5991):538-541. https://doi.org/10.1126/science.1189345

156. Eoh JH, Shen N, Burke JA, Hinderer S, Xia Z, Schenke-Layland K, Gerecht S (2017) Enhanced elastin synthesis and maturation in human vascular smooth muscle tissue derived from inducedpluripotent stem cells. Acta Biomater. https://doi.org/10.1016/j. actbio.2017.01.083

157. Lee SJ, Sohn YD, Andukuri A, Kim S, Byun J, Han JW, Park IH, Jun HW, Yoon YS (2017) Enhanced therapeutic and long-term dynamic vascularization effects of human pluripotent stem cellderived endothelial cells encapsulated in a nanomatrix gel. Circulation. https://doi.org/10.1161/CIRCULATIONAHA.116.026329

158. Serbo JV, Gerecht S (2013) Vascular tissue engineering: biodegradable scaffold platforms to promote angiogenesis. Stem Cell Res Ther 4(1):8. https://doi.org/10.1186/scrt156

159. Dahl SL, Kypson AP, Lawson JH, Blum JL, Strader JT, Li Y, Manson RJ, Tente WE, DiBernardo L, Hensley MT, Carter R, Williams TP, Prichard HL, Dey MS, Begelman KG, Niklason LE (2011) Readily available tissue-engineered vascular grafts. Sci Transl Med 3(68):68ra69. https://doi.org/10.1126/ scitranslmed.3001426

160. Kumar VA, Brewster LP, Caves JM, Chaikof EL (2011) Tissue engineering of blood vessels: functional requirements, progress, and future challenges. Cardiovasc Eng Technol 2(3):137-148. https://doi.org/10.1007/s13239-011-0049-3

161. Kitano K, Schwartz DM, Zhou H, Gilpin SE, Wojtkiewicz GR, Ren X, Sommer CA, Capilla AV, Mathisen DJ, Goldstein AM, Mostoslavsky G, Ott HC (2017) Bioengineering of functional human induced pluripotent stem cell-derived intestinal grafts. Nat Commun 8(1):765. https://doi.org/10.1038/ s41467-017-00779-y

162. Park KM, Hussein KH, Hong SH, Ahn C, Yang SR, Park SM, Kweon OK, Kim BM, Woo HM (2016) Decellularized liver extracellular matrix as promising tools for transplantable bioengineered liver promotes hepatic lineage commitments of induced pluripotent stem cells. Tissue Eng Part A 22(5-6):449-460. https://doi.org/10.1089/ten.TEA.2015.0313

163. Takebe T, Sekine K, Enomura M, Koike H, Kimura M, Ogaeri T, Zhang RR, Ueno Y, Zheng YW, Koike N, Aoyama S, Adachi Y, Taniguchi H (2013) Vascularized and functional human liver from an iPSC-derived organ bud transplant. Nature 499(7459):481-484. https://doi.org/10.1038/nature12271

164. Valarmathi MT, Fuseler JW, Davis JM, Price RL (2017) A novel human tissue-engineered 3-D functional vascularized cardiac muscle construct. Front Cell Dev Biol 5:2. https://doi. org/10.3389/fcell.2017.00002

165. Stevens KR, Kreutziger KL, Dupras SK, Korte FS, Regnier M, Muskheli V, Nourse MB, Bendixen K, Reinecke H, Murry CE (2009) Physiological function and transplantation of scaffoldfree and vascularized human cardiac muscle tissue. Proc Natl Acad Sci USA 106(39):16568-16573. https://doi.org/10.1073/ pnas.0908381106

166. Kawamura M, Miyagawa S, Fukushima S, Saito A, Miki K, Funakoshi S, Yoshida Y, Yamanaka S, Shimizu T, Okano T, Daimon T, Toda K, Sawa Y (2017) Enhanced therapeutic effects of human iPS cell derived-cardiomyocyte by combined cell-sheets with omental flap technique in porcine ischemic cardiomyopathy model. Sci Rep 7(1):8824. https://doi.org/10.1038/ s41598-017-08869-z

167. Smith AS, Davis J, Lee G, Mack DL, Kim DH (2016) Muscular dystrophy in a dish: engineered human skeletal muscle mimetics for disease modeling and drug discovery. Drug Discov Today 21(9):1387-1398. https://doi.org/10.1016/j.drudis.2016.04.013

168. Criswell TL, Corona BT, Wang Z, Zhou Y, Niu G, Xu Y, Christ GJ, Soker S (2013) The role of endothelial cells in myofiber differentiation and the vascularization and innervation of bioengineered muscle tissue in vivo. Biomaterials 34(1):140-149. https://doi.org/10.1016/j.biomaterials.2012.09.045

169. Bach AD, Arkudas A, Tjiawi J, Polykandriotis E, Kneser U, Horch RE, Beier JP (2006) A new approach to tissue engineering of vascularized skeletal muscle. J Cell Mol Med 10(3):716-726

170. Levenberg S, Rouwkema J, Macdonald M, Garfein ES, Kohane DS, Darland DC, Marini R, van Blitterswijk CA, Mulligan RC, D'Amore PA, Langer R (2005) Engineering vascularized skeletal muscle tissue. Nat Biotechnol 23(7):879-884. https://doi. org/10.1038/nbt1109

171. Si-Tayeb K, Lemaigre FP, Duncan SA (2010) Organogenesis and development of the liver. Dev Cell 18(2):175-189. https://doi. org/10.1016/j.devcel.2010.01.011

172. Zaret KS, Grompe M (2008) Generation and regeneration of cells of the liver and pancreas. Science 322(5907):1490-1494. https:// doi.org/10.1126/science.1161431

173. Takebe T, Zhang RR, Koike H, Kimura M, Yoshizawa E, Enomura M, Koike N, Sekine K, Taniguchi H (2014) Generation of a vascularized and functional human liver from an iPSC-derived organ bud transplant. Nat Protoc 9(2):396-409. https://doi. org/10.1038/nprot.2014.020

174. Hsia K, Yao CL, Chen WM, Chen JH, Lee H, Lu JH (2016) Scaffolds and cell-based tissue engineering for blood vessel therapy. Cells Tissues Organs 202(5-6):281-295. https://doi. org/10.1159/000448169

175. Wang C, Cen L, Yin S, Liu Q, Liu W, Cao Y, Cui L (2010) A small diameter elastic blood vessel wall prepared under pulsatile conditions from polyglycolic acid mesh and smooth muscle cells differentiated from adipose-derived stem cells. Biomaterials 31(4):621-630. https://doi.org/10.1016/j. biomaterials.2009.09.086

176. Giacomelli E, Bellin M, Sala L, van Meer BJ, Tertoolen LG, Orlova VV, Mummery CL (2017) Three-dimensional cardiac microtissues composed of cardiomyocytes and endothelial cells co-differentiated from human pluripotent stem cells. Development 144(6):1008-1017. https://doi.org/10.1242/dev.143438

177. Masumoto H, Nakane T, Tinney JP, Yuan F, Ye F, Kowalski WJ, Minakata K, Sakata R, Yamashita JK, Keller BB (2016) The myocardial regenerative potential of three-dimensional engineered cardiac tissues composed of multiple human iPS cellderived cardiovascular cell lineages. Sci Rep 6:29933. https:// doi.org/10.1038/srep29933

178. Germani A, Di Carlo A, Mangoni A, Straino S, Giacinti C, Turrini P, Biglioli P, Capogrossi MC (2003) Vascular endothelial growth factor modulates skeletal myoblast function. Am J Pathol 163(4):1417-1428. https://doi.org/10.1016/ S0002-9440(10)63499-2

179. Ochoa O, Sun D, Reyes-Reyna SM, Waite LL, Michalek JE, McManus LM, Shireman PK (2007) Delayed angiogenesis and VEGF production in CCR2-/- mice during impaired skeletal muscle regeneration. Am J Physiol Regul Integr Comp Physiol 293(2):R651-R661. https://doi.org/10.1152/ajpregu.00069.2007 